\title{
Volcanic stratigraphy and evidence of magma mixing in the Quaternary Payún Matrú volcano, andean backarc in western Argentina
}

\author{
Irene R. Hernando ${ }^{1}$, Eduardo J. Llambías ${ }^{1}$, Pablo D. González ${ }^{1}$, Kei Sato ${ }^{2}$ \\ 1 Centro de Investigaciones Geológicas (CONICET-UNLP), 1 No. 644, B1900TAC, La Plata, Argentina. \\ ihernando@cig.museo.unlp.edu.ar; llambias@cig.museo.unlp.edu.ar; gonzapab@cig.museo.unlp.edu.ar \\ 2 Centro de Pesquisas Geocronológicas (CPGeo), Instituto de Geociências, Universidade de São Paulo (IG-USP), Rua do Lago 562, \\ Cidade Universitária, CEP 05508-080, São Paulo, Brasil. \\ keisato@usp.br
}

\begin{abstract}
The Payún Matrú Volcanic Field is located in the Payenia Basaltic Province of the recent back-arc of western Argentina ( $\left.35^{\circ} \mathrm{S}-38^{\circ} \mathrm{S}\right)$. This province is younger than $5 \mathrm{Ma}$, and most of its volcanic activity took place since 2 Ma. The Payún Matrú Volcanic Field contains two composite volcanoes, Payún Matrú and Payún Liso, and two basaltic fields in an E-W oriented zone, located east and west of the Payún Matrú volcano. Payún Matrú is the largest volcano of this volcanic field, and consists of a shield-shaped edifice with a circular summit caldera of $8 \mathrm{~km}$ in diameter. The composition of both composite volcanoes is alkaline and predominantly trachytic, having also minor intermediate lavas. The basaltic fields consist of basalts and trachybasalts, with clinopyroxene and abundant olivine as phenocrysts and also in the groundmass. Textures indicating mixing and mingling processes, such as dusty plagioclases along with clear ones, biotite replaced by anhydrous minerals and two groundmasses with a fluid-fluid relationship, are common in the early pre-caldera stage of Payún Matrú and some post-caldera lavas. The latest post-caldera lavas are trachytic, with clean sanidine phenocrysts without disequilibrium textures. A remarkable characteristic of the Payún Matrú Volcanic Field is the fact that the Payún Matrú caldera is surrounded by basaltic fields at its base, while no basalts were erupted in the caldera region. We propose that the absence of basaltic lavas in the Payún Matrú volcano is due to the presence of a magmatic chamber below it, and that the mafic magmas rising from deeper levels were unable to erupt without interaction with more evolved melts. Intermediate hybrid magmas produced as a consequence of magma mixing and mingling between basaltic and trachytic magmas, are present in the early and mid-history of Payún Matrú volcano. We present here new information about the Quaternary Payún Matrú Volcanic Field derived from field work, petrography, and major element geochemistry and ${ }^{87} \mathrm{Sr} /{ }^{86} \mathrm{Sr}$ isotopic ratios. For the first time a detailed map of the Payún Matrú Volcanic Field and its volcanic stratigraphy, primarily based on field observations, are presented.
\end{abstract}

Keywords: Payún Matrú caldera, Alkaline basalts, Magma mixing, Back-arc magmatism.

RESUMEN. Estratigrafía volcánica y evidencia de mezcla de magmas en el volcán Payún Matrú del Cuaternario, en el retroarco andino de Argentina occidental. El Campo Volcánico Payún Matrú está localizado en la Provincia Basáltica Payenia, en el retroarco reciente al oeste de Argentina (35ㅇ-38º $)$. Esta provincia es más joven que 5 Ma, y la mayor parte de su actividad volcánica tuvo lugar desde hace 2 Ma. El Campo Volcánico Payún Matrú contiene dos volcanes compuestos, el Payún Matrú y el Payún Liso, así como dos campos basálticos en una franja E-W, ubicados al este y oeste del Payún Matrú. El Payún Matrú es el volcán más grande de este campo volcánico, y consiste en un edificio en forma de escudo con una caldera circular en su cúspide de $8 \mathrm{~km}$ de diámetro. La composición de ambos volcanes compuestos es alcalina y predominantemente traquítica, con menor participación de lavas intermedias. Los campos basálticos consisten en basaltos y traquibasaltos, con clinopiroxeno y abundante olivina como fenocristales, presentes también en la pasta. En la etapa pre-caldera del Payún Matrú y en algunas lavas post-caldera son comunes las texturas que indican procesos de mezcla de magmas, 'mixing' y 'mingling', como plagioclasas cribadas en panal de abejas junto con otras limpias, biotitas reemplazadas por minerales anhidros y la presencia de dos pastas con una relación fluido-fluido. Las lavas post-caldera tardías son traquíticas, con fenocristales limpios de sanidina y sin texturas de desequilibrio. Una 
característica destacable del Campo Volcánico Payún Matrú es el hecho de que la caldera está rodeada por campos basálticos en su base, mientras que no se han producido erupciones de basaltos en la zona de la caldera. Proponemos que la ausencia de lavas basálticas en el volcán Payún Matrú se debe a la presencia de una cámara magmática por debajo del mismo, y a que los magmas máficos que ascienden desde niveles más profundos fueron incapaces de extruirse sin interactuar antes con fundidos más evolucionados. Magmas intermedios híbridos, producidos a consecuencia de la mezcla entre magmas basálticos y traquíticos, están presentes en la historia temprana y media del volcán Payún Matrú. Presentamos aquí nueva información sobre el Campo Volcánico Payún Matrú de edad Cuaternaria, basada en trabajos de campo, petrografía, geoquímica de elementos mayoritarios y relaciones isotópicas de ${ }^{87} \mathrm{Sr} /{ }^{86} \mathrm{Sr}$. Por primera vez se presenta un mapa detallado del Campo Volcánico Payún Matrú y su estratigrafía, basado fundamentalmente en observaciones de campo.

Palabras clave: Caldera del Payún Matrú, Basaltos alcalinos, Mezcla de magmas, Magmatismo de retroarco.

\section{Introduction and Regional Setting}

Although the volcanic arc in the South American Andes is a major feature, the volcanic activity in the back-arc is not so well developed. In the Quaternary Andean back-arc in western Argentina, between $35^{\circ} \mathrm{S}$ and $38^{\circ} \mathrm{S}$, an intense volcanism was developed, mostly of alkaline basalts, in the Payenia Basaltic Province (Polanski, 1954), or simply 'Payenia', also named Andino-Cuyana Basaltic Province (Bermúdez and Delpino, 1989). Payenia is younger than $5 \mathrm{Ma}$, with an increase in the volcanic activity since $2 \mathrm{Ma}$, and it is the largest basaltic province of this age in the back-arc of South America, covering an area of 15,900 km² (Bermúdez et al., 1993; Folguera et al., 2009; Llambías et al., 2010). This province is divided into two basaltic fields: the Llancanelo Volcanic Field in the north, with an area of 10,700 km², and the Payún Matrú Volcanic Field in the south, which covers an area of 5,200 km² (Bermúdez and Delpino, 1989; Bermúdez et al., 1993) (Fig. 1).

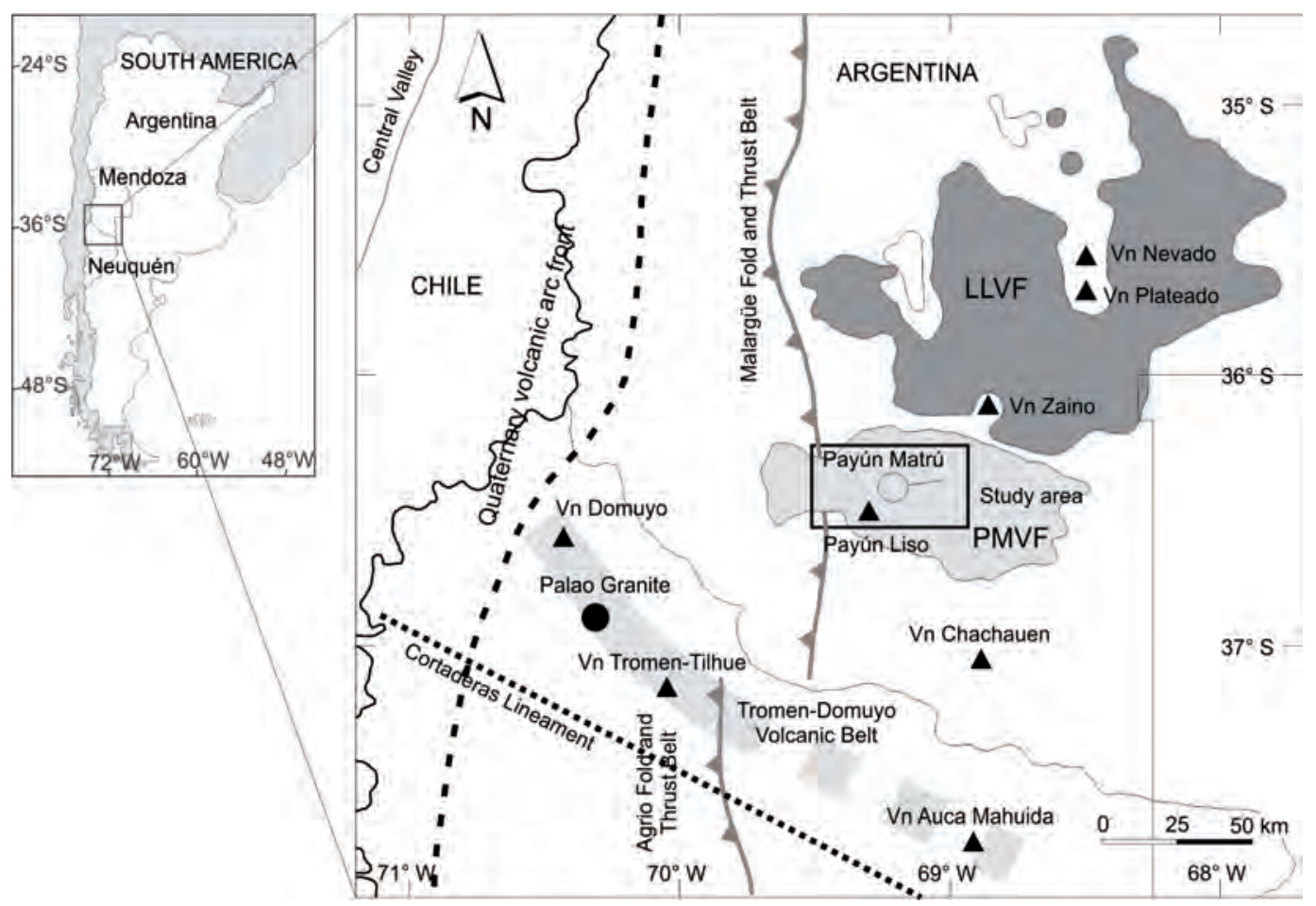

FIG. 1. Location of the Payún Matrú Volcanic Field and the Llancanelo Volcanic Field (LLVF) in the recent Andean back-arc. 
Payenia contains around 800 monogenic basaltic cones, along with a few polygenic volcanoes such as Chachahuén (upper Miocene), Nevado (Pliocene), Auca Mahuida (Pleistocene) and Payún Matrú (upper Pleistocene-Holocene) (Inbar and Risso, 2001a; Llambías et al., 2010). The volcanism in Payenia had two distinct episodes differentiated in age, composition and tectonic affinity (Kay et al., 2006a). The first episode occurred during the late Miocene-Pliocene and it is represented by Chachahuén, Plateado and Nevado volcanoes, which have arc-signatures (Kay et al., 2004; Kay et al. 2006a). The second episode occurred in late Pliocene-Quaternary times with an intraplate affinity and widespread basaltic volcanism in the Llancanelo Volcanic Field and the Payún Matrú Volcanic Field. In this episode, the Payún Matrú, Payún Liso and Auca Mahuida volcanoes were originated (Kay et al., 2006a). In the late early Miocene to late Miocene, between 19 and $5 \mathrm{Ma}$, a period of flat-slab subduction and a compressive regime, are inferred to have peaked in the late Miocene, between 8 and 5 Ma (Kay et al., 2006a; Galland et al., 2007). Evidence for this flat-slab subduction period, among others, is the presence of Chachahuén volcano, located as far as $500 \mathrm{~km}$ from the trench and exhibiting arc chemical signature (e.g., high ratios of $\mathrm{La} / \mathrm{Ta}$ and $\mathrm{Ba} / \mathrm{Ta}$, and low $\mathrm{Ta} / \mathrm{Hf}$, and $\mathrm{Sr}, \mathrm{Nd}, \mathrm{Pb}$ isotopic ratios) (Kay et al., 2006b).

A NW-SE linear structural feature named Cortaderas lineament, located south of Tromen and Auca Mahuida volcanoes, divides the back-arc in two volcanic regions (Fig. 1): 1. North of the lineament the back-arc volcanism from Miocene to Holocene is widespread, and compressional deformation during late Miocene was important, and 2. South of the lineament the back-arc volcanism is nearly absent and the Miocene deformation is not significant (Ramos, 1978; Kay et al., 2006a; Ramos and Kay, 2006; Ramos and Folguera, 2010). The Cortaderas lineament is assumed to be the southern limit of the Miocene flat slab (Kay et al., 2006a). Llambías et al. (2010) proposed the Tromen-Domuyo volcanic belt with the same NW orientation as the Cortaderas lineament, and with its southern limit coinciding with the Cortaderas lineament. This volcanic belt is 40 $\mathrm{km}$ wide and contains three Pleistocene volcanoes (Tilhue, Tromen and Domuyo) and the Palao monzogranite of the same age (Llambías et al., 2010). Auca Mahuida may belong to this volcanic belt, but further studies are needed to affirm or discard the idea (Fig. 1).

The widespread basaltic volcanism in Payenia is thought to be the result of the end of the Miocene flat-slab subduction period and the start of a normal subduction zone, since $5 \mathrm{Ma}$ until present times, which allowed an already hydrated mantle to melt (Kay et al., 2004; Kay et al., 2006a). In this period, there was also a shift to an extensional regime in the back-arc (Kay et al., 2006a; Folguera et al., 2009; Bermúdez et al., 1993). The Payenia basaltic lavas have mainly an intraplate signature, with no depletion in the HFSE typical of arc magmas (Kay et al., 2004; Kay, 2002), and it has been modeled as a result of 2-8\% of partial melting of an enriched mantle source (Kay, 2002). The volume of the Pliocene to Holocene magmatism in this region is difficult to explain based solely on a mantle 'wet spot' in a steep subduction zone, and it was postulated that the mantle has remained hot since Jurassic times, leading to the melting of the mantle by small perturbations (Kay et al., 2006a).

Previous studies of the Payenia Basaltic Province have been focused on the widespread basaltic volcanism, but little has been said about Payún Matrú volcano, in a more local scale. An important feature of the Payún Matrú Volcanic Field is the abundant basaltic volcanism surrounding the Payún Matrú caldera and the lack of basaltic lavas inside the caldera. The absence of basaltic lavas in the Payún Matrú volcano may be explained by the entrapment of the mafic magmas rising from deeper levels with the trachytic magmas located in the Payún Matrú magma chamber.

The aim of this work is to present a detailed geological map, the volcanic stratigraphy and evolution of the Payún Matrú Volcanic Field, and to show evidence of magma mixing as is suggested by satellite images, and supported by petrography and geochemical and isotopic analysis of the different volcanic products of Payún Matrú.

\section{Geology of the Payún Matrú Volcanic Field}

Payún Matrú volcano (3,680 m) located in the center of the Payún Matrú Volcanic Field, stands 2,000 $\mathrm{m}$ above the surrounding plain and has a diameter of $15 \mathrm{~km}$. It presents a summit caldera, which is defined in its northern and southeastern rim by a conspicuous scarp that reaches $450 \mathrm{~m}$ in height (Fig. 2). The remaining caldera rim is 


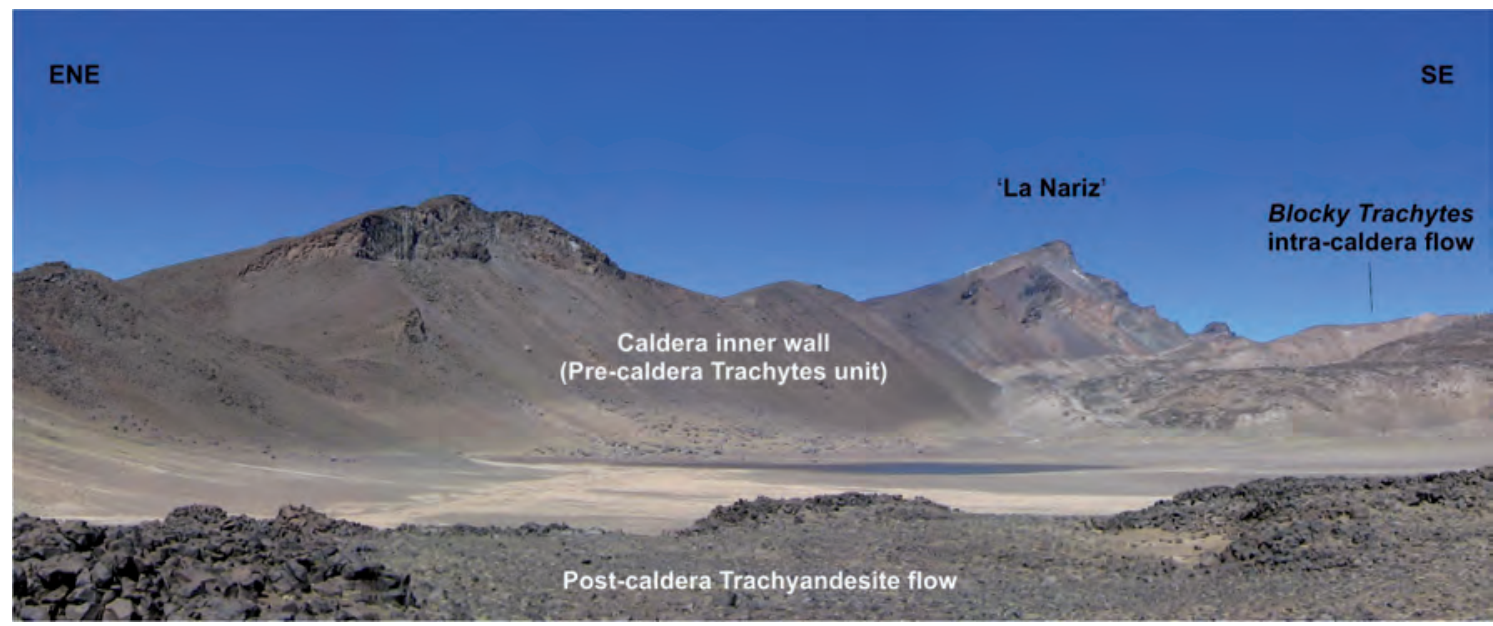

FIG. 2. Interior of the Payún Matrú caldera, showing the eastern inner caldera wall and the two largest post-caldera and intra-caldera lava flows.

defined by numerous domes and pumiceous cones distributed along the annular fractures of the caldera. The caldera was formed by collapse of a previously built volcanic edifice as a consequence of the only volumetrically important explosive eruption, which deposited ignimbrites radially from the caldera, leading to the caldera collapse. East and west of the Payún Matrú caldera, there are two basaltic fields with more than 200 scoria cones distributed in a wide E-W oriented zone (Figs. 3a, b). These basaltic centers were contemporaneous with the evolution of Payún Matrú volcano, and the eruptions of the older basalts were also contemporaneous with the Payún Liso volcano (Llambías, 1966; Germa et al., 2010).

Payún Liso (3,715 m) is a typical cone-shaped stratovolcano of Pleistocene age (Germa et al., 2010) located southwest of Payún Matrú. The growth of this volcano occurred previously to the formation of Payún Matrú caldera (Fig. 3b).

The stratigraphy of the Payún Matrú Volcanic Field was first outlined by Llambías (1966), who postulated a lower Quaternary stage, comprising three volcanic units, and an upper Quaternary stage with four units. The three lower Quaternary units are: 1. La Nariz Andesites and Trachyandesites; 2. Morados Grandes Basalts; 3. El Portezuelo Tuff, further divided in two subunits according to the degree of welding. This unit was later named El Portezuelo Formation (González Díaz, 1972), and it represents the only important explosive eruption. The four upper Quaternary units are: 1. El Mollar
Basalts; 2. La Calle Trachytes; 3. La Explanada Hyalotrachytes, further divided in lavas and pyroclastic deposits; and finally 4. Media Luna Basalts, divided in a lower flow and an upper flow. The age of the Portezuelo Ignimbrite was first proposed to be upper Pleistocene-Holocene (Llambías, 1966; González Diaz, 1970), and later constrained to upper Pleistocene by ${ }^{40} \mathrm{Ar} /{ }^{39} \mathrm{Ar}$ datings of pre- and post-caldera lavas (Germa et al., 2010).

The Llambías (1966) stratigraphic scheme is updated in the present work. We suggest not to use the stratigraphic names given by Llambías (1966) but the new ones proposed in the present work.

\section{Materials and methods}

Detailed field work was carried out in order to perform the geologic mapping at 1:50.000 scale, on the basis of Llambías (1966), and using LANDSAT 7 satellite images from the NASA website and aerial photographs. The storage of geologic information and mapping was made in GIS software. Over 200 samples were collected for petrography and 30 representative samples of different volcanic units were selected for geochemical analysis of major elements, and 9 samples were selected for ${ }^{87} \mathrm{Sr} /{ }^{86} \mathrm{Sr}$ isotopic ratio.

The whole rock geochemical analyses were performed at Activation Laboratories LTD, Ontario, Canada, by lithium metaborate/tetraborate fusion ICP (major and minor oxides). 


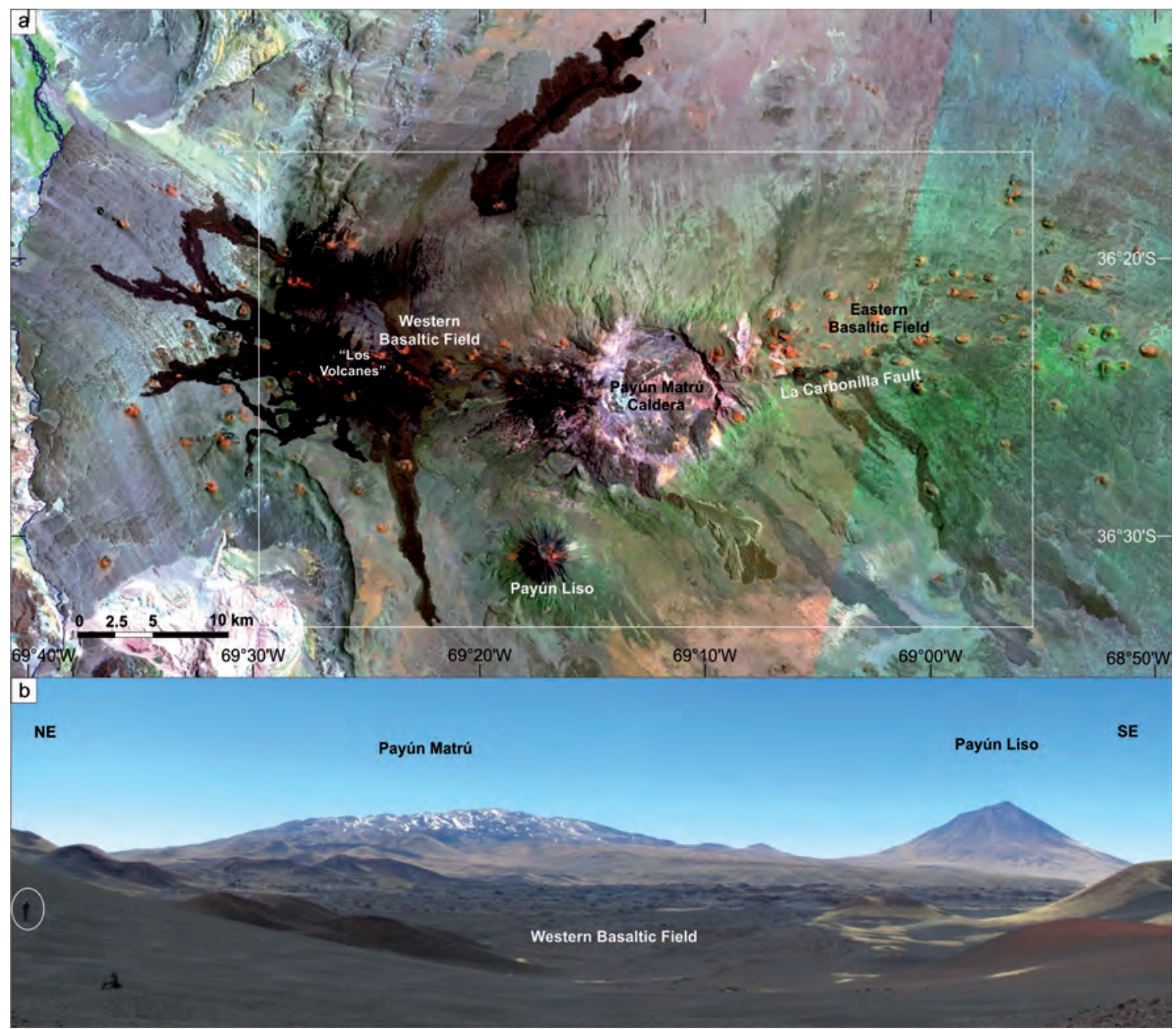

FIG. 3. a. LANDSAT 7 image of the Payún Matrú Volcanic Field, showing the Payún Matrú caldera, the eastern and western basaltic fields and the Payún Liso stratovolcano. The rectangle marks the limit of the map shown on figure 4; $\mathbf{b}$. View from the west of the Payún Matrú and Payún Liso volcanoes showing their different morphologies, along with the western basaltic field. See the person for scale inside the circle.

One out of two selected ignimbrites belongs to fiamme fragments (sample PMB 4), representing directly the juvenile composition (sample PM 14), and the other represents the bulk rock composition, which has a low content of lithic fragments $(<2 \%)$.

The whole rock samples preparation (crushing, milling) was performed at the Centro de Investigaciones Geológicas (Universidad Nacional de La Plata). Powdered whole rock samples for Strontium isotope analysis were treated at clean Rb-Sr Laboratory of the same institution with $\mathrm{HNO}_{3}-\mathrm{HF}$, and natural Sr separated through resin columns following the technique described by Varela et al. (2000).
XRF determinations for $\mathrm{Rb}$ and $\mathrm{Sr}$ contents as well as mass spectrometry were performed at Centro de Pesquisas Geocronologicas (CPGeo), Universidad de São Paulo, Brazil. The mass spectrometry was performed in the 'Thermal Ionization Mass Spectrometer' (TIMS) model MAT262-multicollector-Finnigan Mat. The normalization value is ${ }^{87} \mathrm{Sr} /{ }^{86} \mathrm{Sr}=0.1194$ and analytical error is quoted as $2 \sigma$. Other analytical conditions were NBS 987 standard value to ${ }^{87} \mathrm{Sr} /{ }^{86} \mathrm{Sr}$ ratio $=0.710250 \pm 0.000008$ (mean value), and the spike utilized to Isotopic Dilution (if $\mathrm{Sr}$ is low concentration) was spike ${ }^{84} \mathrm{Sr}$. 


\section{Results}

\subsection{Volcanic stratigraphy}

Volcanic units were defined based on their occurrence either in polygenic volcanoes or in monogenic cones, their morphology, eruptive style and composition of magmas. In this way, basalts belonging to the eastern and western basaltic fields are separated from Payún Matrú and Payún Liso volcanoes. As the Portezuelo Ignimbrite is the only deposit of its kind in the Payún Matrú Volcanic Field, and marks an important event in the evolution of Payún Matrú, it is defined as a single unit. It also serves as a reference horizon due to its widespread areal distribution. An important discrimination criterion for both the composite volcanoes and the basaltic fields is the stratigraphic position of the different units with respect to the Portezuelo Ignimbrite. All volcanic units are grouped in a pre-, syn-, and a post-caldera stage. The basaltic fields were divided into three units, named Pre-caldera Basalts, Post-caldera Basalts I and Post-caldera Basalts II. The Payún Matrú volcano was divided into four units: Pre-caldera Trachytes, Portezuelo Ignimbrite, Post-caldera Trachyandesites, and finally Post-caldera Trachytes. The Post-caldera Trachytes unit was further divided into three lithofacies, according to their different morphologies and effusive or explosive eruption styles. These three lithofacies were named Blocky Trachytes, Pumice cones and Vitreous Trachytes. The Payún Liso volcano was grouped in a single unit since it is not the object of the present study. The correspondence between the stratigraphy by Llambías (1966) and the new stratigraphy proposed in this work is shown in figure 4. The Post-caldera Trachyandesites unit corresponds to some, but not all, of the lava flows present in the caldera region previously grouped in the El Mollar Basalts unit (Llambías, 1966). The Post-caldera Basalts I unit corresponds to lava flows of El Mollar Basalts which were not included in Post-caldera Trachyandesites unit, and also to the lower flows of Media Luna Basalts.

The geological map of the Payún Matrú Volcanic Field is presented in Fig. 5, and a general stratigraphic scheme in figure 6.

\subsubsection{Payún Matrú}

\subsubsection{Pre-caldera stage}

The Pre-caldera Trachytes is the oldest unit of Payún Matrú volcano. It is composed mostly by lava flows and domes of trachytic compositions, with fewer trachybasalts and basaltic trachyandesites. Scarce radial dykes and volcaniclastic rocks of the same compositions are also present. This unit has outcrops in the exposed caldera wall and in the NE to SE outer slopes of the caldera (Figs. 2 and 5). The highest altitude of the caldera scarp is

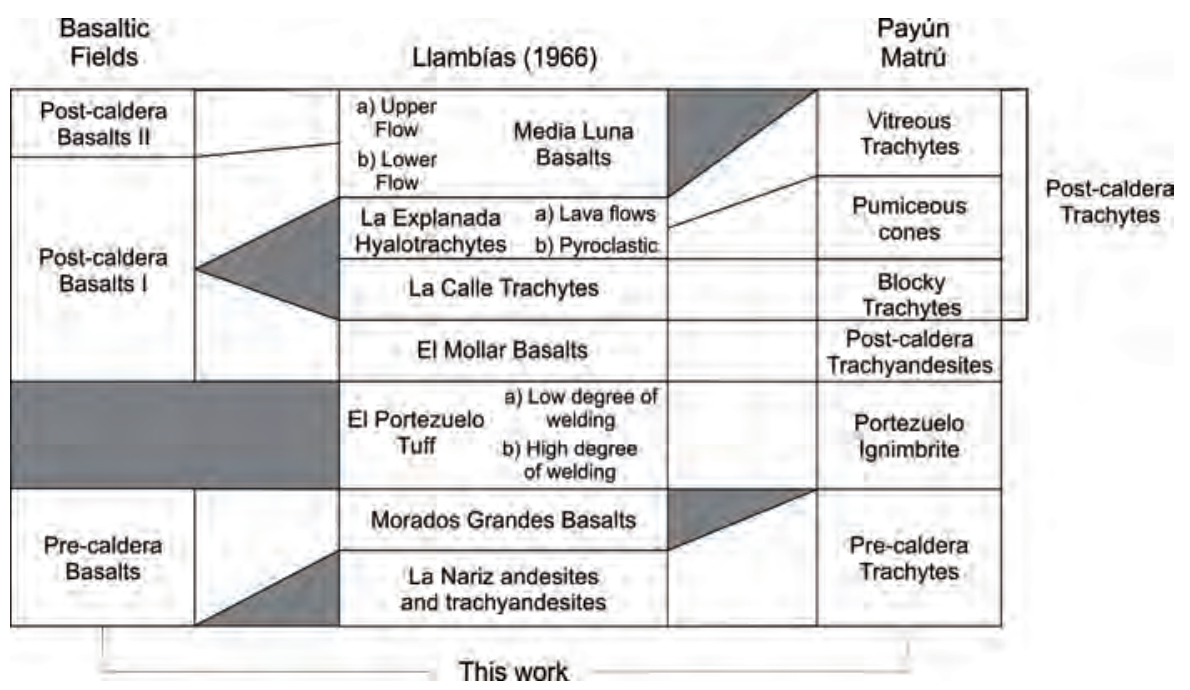

FIG. 4. Diagram showing the correspondence between the Llambías (1966) stratigraphy and the one proposed in this work. 


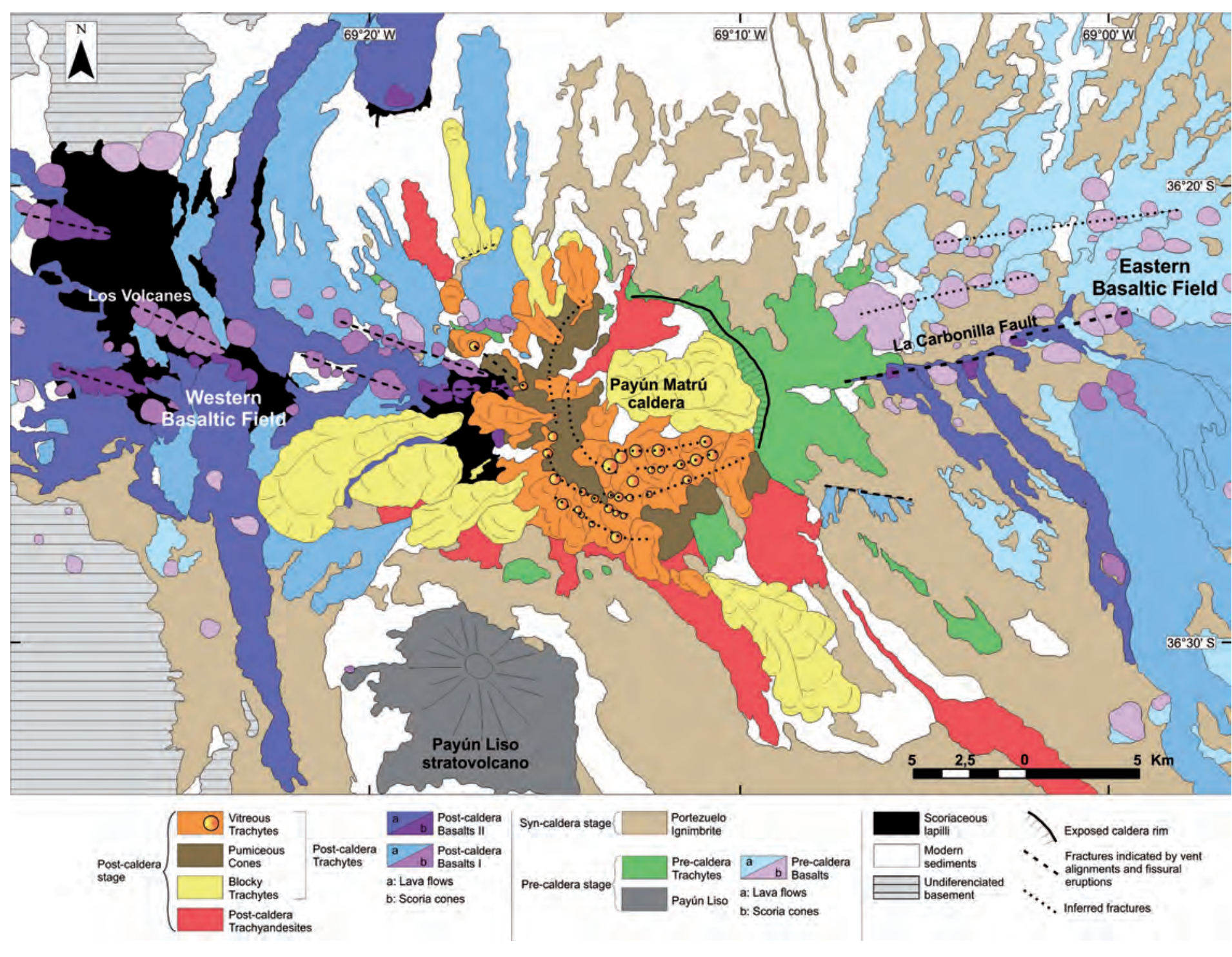

FIG. 5. Geologic map of the Payún Matrú Volcanic Field. The fractures are coeval with the basaltic eruptions. 


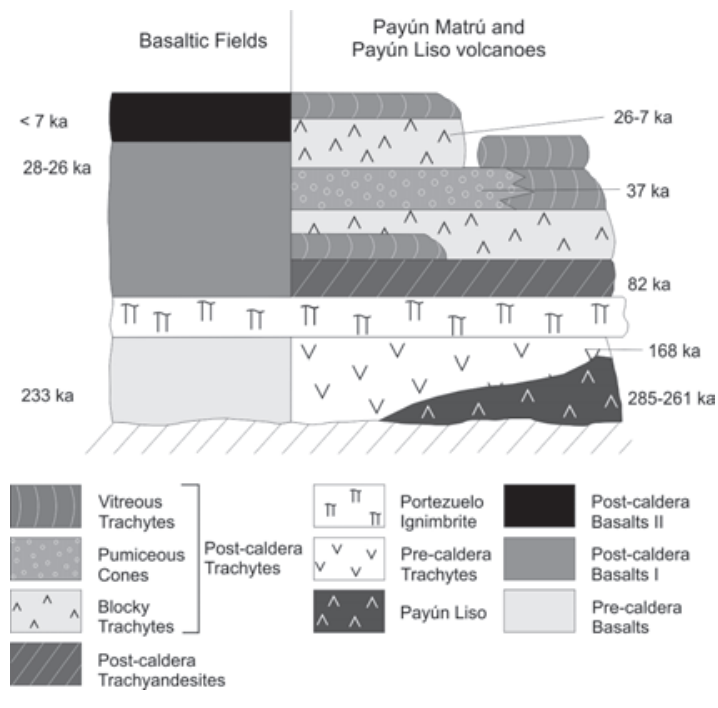

FIG 6. Stratigraphic scheme for the Payún Matrú Volcanic Field that shows the contemporaneous volcanic activity of the basaltic fields and Payún Matrú. ${ }^{40} \mathrm{Ar} /{ }^{39} \mathrm{Ar}$ ages from Germa et al. (2010).

in its NE zone ('La Nariz'), with 450 m of exposed caldera wall (Fig. 2). Trachytic lava outcrops are partially to almost completely covered by ignimbrites on the southern zone of Payún Matrú. This unit was considered to be Pleistocene by Llambías (1966), and was recently dated in $168 \pm 4$ ka by ${ }^{40} \mathrm{Ar} /{ }^{39} \mathrm{Ar}$ in groundmass of trachytic lava (Germa et al., 2010).

\subsubsection{Syn-caldera stage}

This stage is represented by the trachytic Portezuelo Ignimbrite, which is dispersed radially from the caldera up to a distance of about $40 \mathrm{~km}$. There are no exposures of this unit inside the caldera due to the important and voluminous post-caldera volcanism. The intra-caldera ignimbrite, if present, is completely covered. The outcrops extend mostly north and south of the caldera rim, but they are partially covered by post-caldera basaltic flows and scoria cones in the eastern basaltic field, and almost completely covered in the western basaltic field (Figs. 5 and 3b). The ignimbrite is mostly massive, generally with a medium grade of welding except in some lower parts of its profile where it is highly welded. Its thickness varies widely, from less than $0.5 \mathrm{~m}$ to more than $20 \mathrm{~m}$. Due to the discontinuity of the outcrops, the highly variable thickness, the fact that the base of the ignimbrite is not always exposed and the lack of subsurface information about the presence or absence of an intra-caldera ignimbrite, its volume is hard to determine precisely but it is estimated to be around $30 \mathrm{~km}^{3}$ (dense rock equivalent) (Llambías et al., 2010). The widespread outcrops of the Portezuelo Ignimbrite in the region between Payún Liso and Payún Matrú volcanoes are eroded by the strong winds typical of this region, forming yardangs oriented NW-SE, the main wind direction (Llambías, 1966; Inbar and Risso, 2001b). The ${ }^{40} \mathrm{Ar} /{ }^{39} \mathrm{Ar}$ datings of pre- and post-caldera lavas constrain the age of this unit to upper Pleistocene, between $168 \mathrm{ka}$ and $82 \mathrm{ka}$ (Germa et al., 2010).

\subsubsection{Post-caldera stage}

It is represented by two different units in terms of composition and morphology:

a. Post-caldera Trachyandesites: These are the first lavas erupted after the caldera collapse. They are basaltic trachyandesitic to trachyandesitic lava flows, representing a marked shift towards less evolved products with respect to the Portezuelo Ignimbrite. These lavas were erupted through the annular fractures of the caldera and flowed over the S and NW slopes of Payún Matrú, and also inside its caldera (Fig. 5). The lavas erupted in the southern caldera slope resemble pahoehoe flows, showing smooth surfaces, tumuli and ropy texture, while the only intra-caldera lava flow has a blocky and hummocky surface with poorly developed levées, resembling aa lava morphology (Fig. 2). Their lengths vary from those typical for blocky lavas (a few $\mathrm{km}$ ) to those typical for a basaltic lavas in the Payún Matrú Volcanic Field (up to 18 km in length). The intra-caldera lava flow was dated in $82 \pm 2$ ka by ${ }^{40} \mathrm{Ar} /{ }^{39} \mathrm{Ar}$ dating in groundmass (Germa et al., 2010).

After the eruptions of these intermediate lavas of the Post-caldera Trachyandesites unit, there was again an abrupt change in the composition of the emitted products, shifting to a more homogeneous trachytic composition. This latest stage of the post-caldera stage is grouped in a single unit, Post-caldera Trachytes, and further subdivided into three distinct lithofacies named above. The complexity of the stratigraphic relationship between these three lithofacies, along with the homogeneity of their compositions, was the reason for grouping them in a single unit. As an example, in the NW and SW rim of the caldera the Blocky Trachytes lavas are covered by Vitreous 
Trachytes lavas and Pumice cones deposits (Fig. 5), but the Blocky Trachytes intra-caldera lava flow is younger than Pumice cones deposits. The pumice cones lithofacies are restrained between Blocky Trachytes and Vitreous Trachytes lavas, and the time span of the Vitreous Trachytes overlaps that of the Blocky Trachytes unit. The description of these three lithofacies is as follows:

b. Blocky Trachytes: This lithofacies comprises the lava flows with a characteristic blocky morphology erupted through the caldera annular fissures and in the NW and SE flanks of Payún Matrú. They are up to $9 \mathrm{~km}$ in length and $250 \mathrm{~m}$ in thickness, a common range for this type of lava flows (Figs. 2 and 5). They possess strongly developed morphologic features of blocky lavas like lobes, levées and pressure ridges. Three ${ }^{40} \mathrm{Ar} /{ }^{39} \mathrm{Ar}$ ages of these lavas range from $26 \pm 2$ ka (NW caldera slope flow) to $7 \pm 1$ ka (intra-caldera flow) (Germa et al., 2010). Some other flows which were erupted in the southern and northwestern rim of the caldera, partially covered by the Pumice cones and Vitreous Trachytes lithofacies, may be older.

c. Pumiceous cones: These cones are moundshaped deposits with circular to elongated bases, with a diameter/length of up to 1,300 m (Fig. 7a), and which were erupted along the southeastern to the northern rim of the caldera (Fig. 5). These deposits are almost entirely composed of light gray to reddish trachytic pumice fragments, including minor contents of black glassy bombs with polygonal shapes, also of trachyte. The pumiceous cones constitute pyroclastic deposits with a very low to high degree of welding and a very poor selection, comprising glassy bombs of up to $1 \mathrm{~m}$ of diameter along with pumice clasts from milimetric to tens of centimeters in size. The deposits are clast supported and lack fine matrix, showing a diffuse coarse stratification. The pumice cones are closely related to the vitreous trachytes, in the sense that the vitreous black bombs are of the same composition and texture as the vitreous trachytes lithofacies, and that a few flows have a pumice layer on its base or flow from a pumice cone. On the NW inner rim of the caldera, sanidine from pumice fragments were dated in $37 \pm 2$ ka (Germa et al., 2010).

d. Vitreous Trachytes: This lithofacies is represented by a number of small domes and coulées, with fewer but longer lava flows (Fig. 7b). They are mostly distributed along the southern and western rim of the caldera, with few representatives in the western lower flank of Payún Matrú (Fig. 5). The domes are

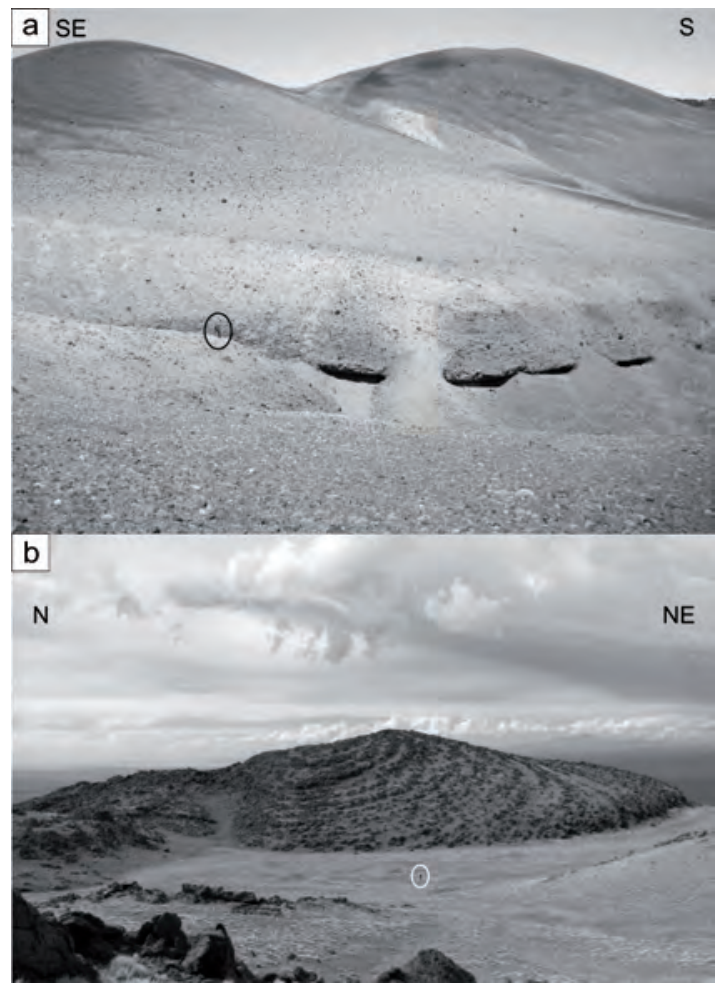

FIG. 7. a. Two pumiceous cones in the western caldera rim. See the person inside the circles for scale; $\mathbf{b}$. View of a lava of the Vitreous Trachyte lithofacies in the northern caldera rim.

circular in plain view, ranging from $150 \mathrm{~m}$ to 1,000 $\mathrm{m}$ in diameter, and the lava flows are shorter than that of the Blocky Trachytes lithofacies, reaching $3.5 \mathrm{~km}$ in length. Pressure ridges are conspicuous and are more closely spaced than in the blocky lavas of Blocky Trachytes lithofacies (Fig. 7b). There are no ages available for this lithofacies.

\subsubsection{Payún Liso}

Payún Liso stratovolcano (Figs. 3a, 3b and 5) belongs to the pre-caldera stage. It is contemporaneous or slightly older than the early eruptions of Payún Matrú, as indicated by the partial cover of its northern slope by the Portezuelo ignimbrite and also by four ${ }^{40} \mathrm{Ar} /{ }^{39} \mathrm{Ar}$ dates in groundmass of lavas, ranging between $261 \pm 4 \mathrm{ka}$ and $285 \pm 5 \mathrm{ka}$ (Germa et al., 2010). The Payún Liso volcano mostly comprises lavas with minor pyroclastic rocks. The lavas are trachytic to trachyandesitic, similar to that of the 
pre-caldera stage of Payún Matrú. On its N and NE flank, the Portezuelo Ignimbrite reaches an altitude of nearly $300 \mathrm{~m}$ above the base of Payún Liso volcano. Payún Liso has a volume estimated in $40 \mathrm{~km}^{3}$ (Germa et al., 2010), and its morphology is different from that of Payún Matrú, with a clearly defined central vent and steeper slopes, as for a typical stratovolcano.

\subsubsection{Basaltic fields}

The numerous basaltic eruptions in the eastern and western basaltic fields were contemporaneous with the Payún Matrú volcano, as proposed by Llambías (1966), and later corroborated by ${ }^{40} \mathrm{Ar} /{ }^{39} \mathrm{Ar}$ ages in pre- to post-caldera basaltic lavas, which range from $233 \pm 11$ ka to $<7$ ka (Germa et al., 2010).

These basaltic fields are separated by the Payún Matrú caldera, with almost no eruptions south and north of the caldera region. The lavas are alkaline basalts and trachybasalts, with a tendency of the younger Post-caldera Basalts II unit to be trachybasalts and the older Pre-caldera Basalts unit to be basalts, with the Post-caldera Basalts I in between the two, suggesting a continuous trend. The two post-caldera basaltic units are separated on the basis of their stratigraphic position (Postcaldera Basalts II cover the lavas of Post-caldera basalts I), on their degree of preservation and on the sedimentary and/or vegetal cover of the lavas and scoria cones. The surface morphology of the younger Post-caldera basalts II flows is aa in all cases, with rugged surfaces and a principal central lava channel surrounded by wide 'levées'. The flows reach lengths up to $21 \mathrm{~km}$. The scoria cones associated with these flows have frequently abundant bombs in an in situ position, with aerodynamical or irregular shapes. Morphological studies in scoria cones belonging to this unit indicate that they are Holocene (Inbar and Risso, 2001a), as does an ${ }^{40} \mathrm{Ar} /{ }^{39} \mathrm{Ar}$ date in basalt groundmass of $<7 \mathrm{ka}$ (Germa et al., 2010). Older basalts of Post-caldera Basalts I and Pre-caldera Basalts units are mostly compound flows with pahoehoe morphology, showing smooth surfaces and the development of tumuli and lava tubes in a few cases. In the eastern region of the eastern basaltic field, there is a pahoehoe lava flow named 'Pampas Onduladas' (only its proximal area is visible in Fig. 3a, outside the inset, near the NE corner of the image), which has a total length of $181 \mathrm{~km}$ and is considered the longest Quaternary lava flow on Earth (Pasquarè et al., 2008). In both western and eastern basaltic fields there are pre- and post-caldera basalts, but there is a marked contrast in their relative abundances to either side of the caldera region. In the eastern field the outcrops of pre-caldera basalts are widespread, especially north of the Carbonilla Fault, were no basalts were erupted in the post-caldera stage (Fig. 5). The younger basalts of Post-caldera Basalts II unit are mostly distributed on the western side of Payún Matrú caldera, in 'Los Volcanes' region, where the basaltic flows are still not covered by vegetation and a blanket of lapillitic scoria covers older flows (Figs. 3b and 5). Very few outcrops of basaltic scoria cones and lava flows of the pre-caldera stage are still visible in this region (Fig. 5).

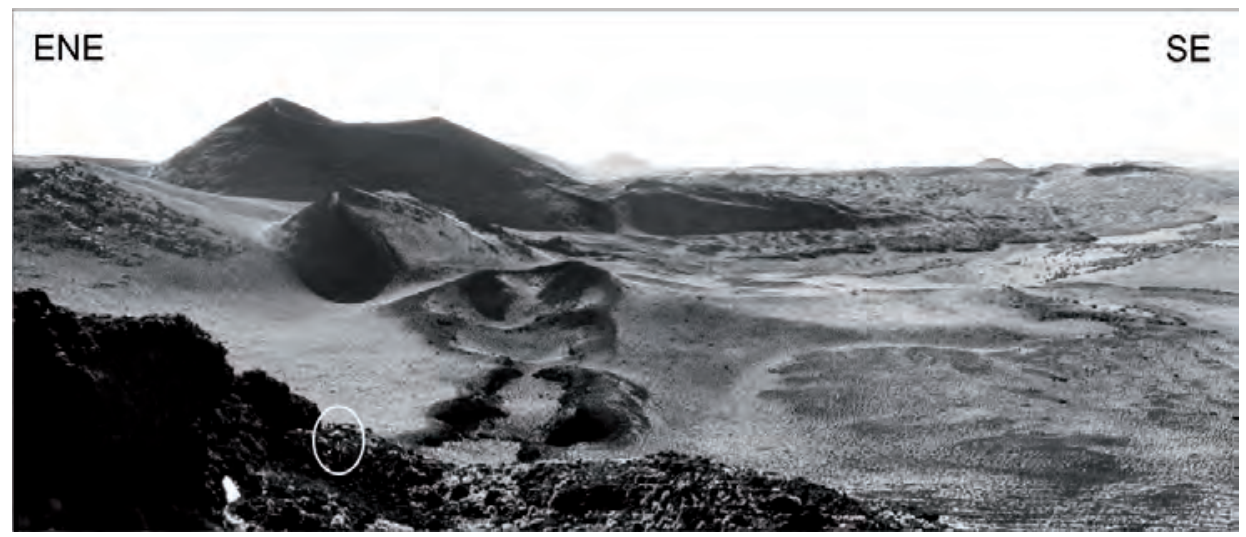

FIG. 8. Photo of a basaltic fissure eruption along La Carbonilla fault in the eastern basaltic field, showing the main scoria cone and small fissure ridges aligned in a E-W orientation. See the person inside the circle for scale. 


\subsection{Structural controls on volcanism}

Fractures clearly control the location of the eruptions of both the basaltic lava fields and the more silicic rocks of Payún Matrú. In first place, there are fisural eruptions with E-W and NW-SE orientations in the basaltic fields and distributed over a relatively wide area (Fig. 5). In second place, there are more local annular structures related to the caldera collapse and located in the caldera region. The eruption of basaltic lavas occurred along linear fissures, as seen in La Carbonilla Fault (Figs. 3a and 5) with fissure ridges and a scoria cone aligned in $\mathrm{E}-\mathrm{W}$ direction (Fig. 8). Outside the zone of La Carbonilla Fault, vent alignments are not so obvious but seem to follow the same orientation (Fig. 5). In the western basaltic field, vent alignments marked by few scoria cones and fissure ridges in NW directions are common and noticeable, with minor E-W vent alignments (Fig. 5). Not only are the basaltic vents aligned in NW directions, but also there is one marked alignment of pumice cones and lava flows of Vitreous Trachytes lithofacies on the western slope of the caldera with the same orientation (Fig. 5). This alignment has the same orientation as the scoria cones near them, and it shows that the younger units of Payún Matrú are not only controlled by the annular fractures of the caldera collapse but they are also controlled, at least in this region, by the same type of fractures that control the basaltic volcanism.

The caldera structure is clearly visible along the north to the southeast rim, where there is a scarp of less than $10 \mathrm{~m}$ (northern rim) to $450 \mathrm{~m}$ (eastern rim) (Figs. 2 and 5). No post-caldera eruptions along this zone of the caldera rim were emitted. The remaining rim of the caldera is not so clearly defined; it is indicated by a wide annular zone where numerous post-caldera eruptions took place. The distribution of the trachytic vents of lava flows, 'coulées', domes and pumiceous cones shows that there are annular fractures and that the caldera rim is wider in this zone. A few lava flows erupted relatively far from the caldera rim, on its southeast and northwest slopes (Fig. 5).

\subsection{Petrography}

\subsubsection{Pre-caldera stage}

a. Pre-caldera Trachytes unit: The petrography of this unit is not simple and uniform. They present in most cases a variety of disequilibrium textures and, in a few cases, inclusions of more mafic magmas. The rocks are all porphyritic with plagioclase that predominates over sanidine. Clinopyroxene is always present and predominates over olivine, biotite and amphibole in this order of abundance. Biotite and amphibole are not always present and apatite is a common accessory phase. Sanidine phenocrysts (12-20\%) are clean and euhedral, up to $4 \mathrm{~mm}$ in size. Plagioclase crystals (8-20\%) have textures that vary widely, even in the same sample. Commonly, there are euhedral and clean crystals along with more anhedral crystals which show either dusty o coarse sieved zones (Fig. 9a). Clinopyroxene (up to $3 \%$ ) is subhedral to euhedral, and up to $2 \mathrm{~mm}$ in size. It is sometimes rounded, and the occurrence of rounded and non-rounded phenocrysts in the same sample is common. Olivine phenocrysts (1-3\%) are subhedral up to $1 \mathrm{~mm}$ in size, generally less than $0.5 \mathrm{~mm}$. They are rounded and present a slight alteration to iddingsite. Biotite (up to $2 \%$ ) is subhedral, up to $1 \mathrm{~mm}$ in size and it shows a reaction rim with anhydrous minerals that in some cases replaces the whole crystal (Fig. 9b). The amphibole (2\%) is generally anhedral, up to $1 \mathrm{~mm}$ in size and it displays a medium brown to a darker reddish brown pleocroism. It always exhibits an opaque rim (Fig. 9c). Blobs of a different magma without quench textures and showing a fluid-fluid relationship with the host magma are present in a few trachytic and trachyandesitic samples (Fig. 9d). These same samples also have phenocrysts with disequilibrium textures, like sieved and unsieved plagioclase phenocrysts and biotite with reaction rims.

\subsubsection{Syn-caldera stage}

a. Portezuelo Ignimbrite unit: The ignimbrite is ash-rich, with abundant crystals of sanidine and plagioclase, with minor contents of olivine, clinopyroxene, biotite and opaque minerals, and apatite as an accessory mineral. The feldspars (up to 25\%) are seriate up to $2 \mathrm{~mm}$ in size. They are generally clean except for minor amounts of subhedral and anhedral sieved crystals, with a sieved texture that is slightly coarser than dusty zones (Fig. 9e). Fragmented crystals and glomerocrysts are common. Olivine and clinopyroxene have similar low abundances, 1 to $2 \%$. They are euhedral to subhedral and fresh, 


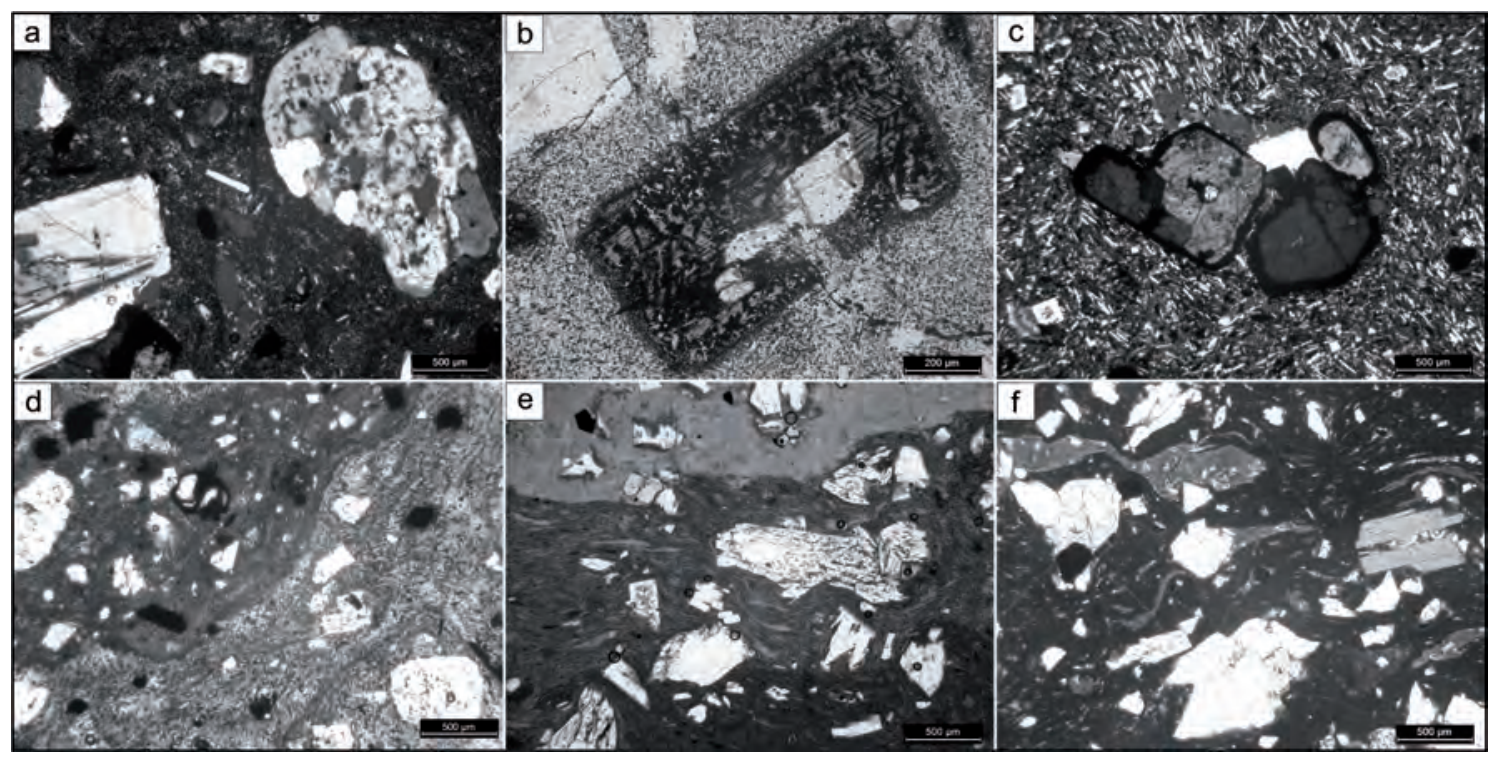

FIG. 9. Microphotographs of Pre-caldera Trachytes (a-d) and the Portezuelo Ignimbrite (e-f). a. Two plagioclase phenocrysts in a trachyte lava with different textures: one clean, euhedral and showing slightly rounded corners, and the other rounded with a coarse sieve texture; b. Biotite phenocrysts partially replaced by an anhydrous mineral association; c. Glomerocryst of amphibole with an opaque rim; d. Two different groundmasses showing a fluid-fluid relationship, indicating magma mingling processes; e. Sieved plagioclase crystals in the Portezuelo Ignimbrite with a high grade of welding, along with a few olivine crystals; f. Biotite, clinopyroxene and sanidine crystals in the same ignimbrite. Biotite is euhedral and shows no replacement textures.

less than $1 \mathrm{~mm}$ in size. Biotite (1\%) shows no signs of reaction with the melt (Fig. 9f). Pummice fragments range in degree of compaction from those with globular shapes and highly vesicular to fiamme with lenticular shapes (Figs. 9e and 9f). Their sizes can vary widely, from millimeter to 1 meter long in fiamme present in the lower part of the north scarp of the caldera rim profile. Basaltic to trachytic lithic fragments are generally scarce, up to a few tens of centimeters in size.

\subsubsection{Post-caldera stage}

a. Post-caldera Trachyandesites unit: This unit is by far the most variable among the post-caldera rocks, both in composition and in mineralogical textures. All lava flows possess disequilibrium textures, especially in plagioclase phenocrysts. They are porphyritic, with plagioclase as the most abundant phase, plus olivine and clinopyroxene. Apatite is also a common accessory mineral. The groundmass is intergranular and more rarely pilotaxitic. Plagioclase phenocrysts are abundant (15-22\%) and seriated, up to $4 \mathrm{~mm}$ in size. Dusty zones in euhedral pla- gioclase phenocrysts are widespread and they are distributed in several ways, most commonly in the core of the crystal with clear overgrowths, or in a rim leaving a clear core. Euhedral and clear crystals are also common, and sieved and clear crystals may occur side by side in the same sample (Fig. 10a). Coarse sieved textures with groundmass inclusions of up to a few tens of micrometers or, more rarely, a few hundred micrometers in size occur in some euhedral plagioclases, distributed in cores or rims, and can be present along dusty zones in the same crystals (Fig. 10b). Olivine (up to 5\%) is subhedral, seriated up to $1 \mathrm{~mm}$ in size, and it presents, in some cases, rounded corners and an incipient alteration to iddingsite. Clinopyroxene (up to 5\%) is subhedral, with rounded and non-rounded corners present in the same sample, up to $1.5 \mathrm{~mm}$ in size. The intra-caldera lava flow possesses evidence of mingling involving two melts of different compositions, with few pockets of trachytic magma immersed in less evolved basaltic trachyandesitic lava, which constitutes the vast majority of the flow. Although these two melts have the same mineralogical association, they have different textures in groundmass and plagioclase 


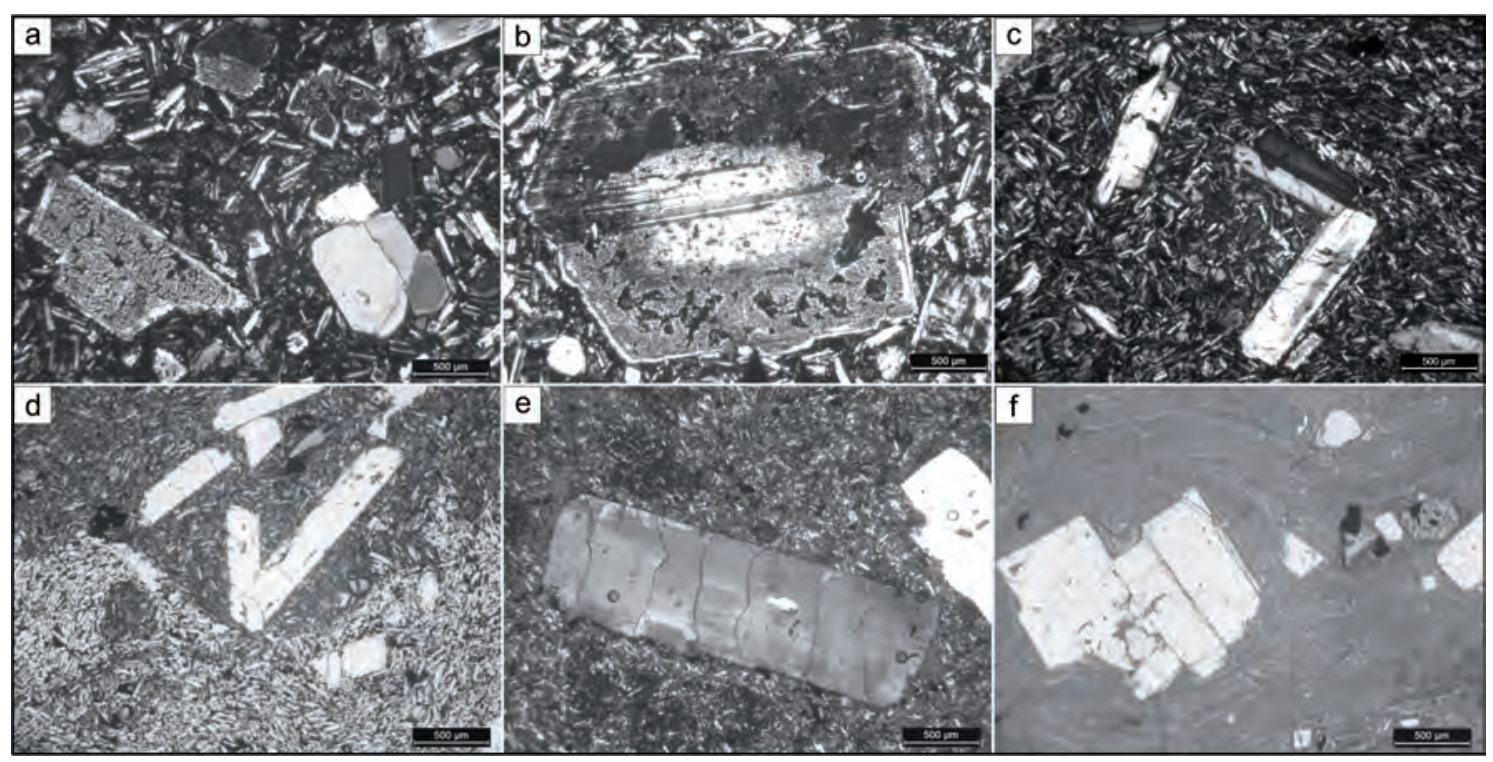

FIG. 10. Microphotographs of the intra-caldera lava flow of the Post-caldera Trachyandesites unit (a-d), and lavas from the Blocky Trachytes lithofacies (e) and Vitreous Trachytes lithofacies (f) of the Post-caldera Trachytes unit. a. Clean and euhedral plagioclase phenocryst, along with a euhedral and dusty crystal with a clear rim; b. Plagioclase phenocrysts showing a clear core with a dusty rim that also shows a coarse sieved texture with groundmass inclusions; c. Clean and euhedral plagioclase phenocrysts in a pilotaxitic groundmass. This sample belongs to the trachytic pockets immersed in the basaltic trachyandesitic intra-caldera lava flow; $\mathbf{d}$. Two melts of different composition and texture in the same lava flow, indicating mingling; e. Clean and euhedral sanidine phenocryst in a pilotaxitic groundmass, intra-caldera trachytic lava flow; f. Vitrophyre with euhedral sanidine and clinopyroxene phenocrysts. Note a few glass inclusions in the sanidine crystal, which are controlled by cleavage directions.

phenocrysts (Figs. 10a, c, d). Plagioclases in the trachytic pockets are basically of two types: the most common one is subhedral with rounded corners and a marked zonation in the outer margin, and the other shares the same characteristics but it also has a coarse sieved texture. The plagioclase phenocrysts in the basaltic trachyandesitic portion are mainly euhedral, with clean and dusty or coarse sieved crystals coexisting in the same sample, and with minor anhedral, coarse sieved and dusty plagioclases (Figs. 10a, b).

b. Post-caldera Trachytes unit: Although this unit shares many petrographic characteristics among its three lithofacies, they have also differences and they will be described separately:

Blocky Trachytes lithofacies: These are light gray trachyte lavas, mainly composed of sanidine phenocrysts (8-15\%), clinopyroxene (2-3\%) and minor contents of biotite (1\%), which is not always present. Olivine is scarce, and apatite occurs as an accessory mineral. Groundmass is holocrystalline, with pilotaxitic and/or trachytic texture. sanidine phenocrysts are seriate, up to $5 \mathrm{~mm}$ long, mainly clean and euhedral without signs of reaction with the melt (Fig. 10e). The clinopyroxene is abundant, subhedral to euhedral and shows a narrow opaque rim. Biotite is of $1 \mathrm{~mm}$ in size and it is almost completely replaced by opaque minerals. Glomeroporphyritic texture with sanidine plus mafic minerals is common.

Vitreous Trachytes lithofacies: They are composed of black porphyritic vitrophyres. They have abundant sanidine phenocrysts as the $T b q$ lithofacies, with clinopyroxene (2-4\%), lesser amounts of olivine (1-2\%), opaque minerals and in a few cases biotite $(<1 \%)$. Apatite is an accessory mineral. Glass is partially recrystallized in discontinuous bands of variable thickness, from millimeters to tens of centimeters. Sanidine phenocrysts are seriate up to $4 \mathrm{~mm}$ in size. They are always clean with euhedral shapes, some of them showing glass inclusions controlled by the cleavage directions and without rounding of the corners (Fig. 10f). Sanidine microlites with 'swallow tail' morphologies are frequent. Clinopyroxene is also seriate, ranging between 0.1 
and $1.2 \mathrm{~mm}$ in size, euhedral and showing no signs of disequilibrium with the melt, such as rounded corners or mantles. Olivine is less abundant, $1 \mathrm{~mm}$ in size approximately and commonly with rounded corners and an incipient alteration to iddingsite. Biotite is scarce and not always present, seriated up to $1 \mathrm{~mm}$ long and sometimes replaced by opaque minerals. Glomeroporphyritic texture, with sanidine \pm clinopyroxene and opaque minerals is common.

Pumice cones lithofacies: The pumice fragments are light gray to reddish and porphyritic. The type and abundances of phenocrysts are identical to those of the $T v$ lithofacies described above. They differ from the $T v$ lithofacies only in the degree of vesiculation and fragmentation of the lava, a result of the more explosive eruptions that formed these pyroclastic deposits.

\subsubsection{Basalts from Pre- and Post-caldera units}

The three basaltic units are porphyritic or microporphyritic, mainly composed of plagioclase and olivine, and generally with minor clinopyroxene and opaque minerals. There are exceptions to this general rule, with some basalts without plagioclase phenocrysts and some others without clinopyroxene; olivine is always present, both in the groundmass and as phenocrysts. These differences in the content of phenocrysts are not correlated with the chemical evolution of the basaltic units (discussed later), although there is a tendency in the younger Postcaldera Basalts II to have slightly higher phenocrysts content. The groundmass is intergranular with the same mineralogy, except that the amount of clinopyroxene is markedly lower and olivine is by far the most abundant mafic microlite, frequently showing skeletal morphologies. Plagioclase phenocrysts are mostly euhedral and clean, seriate up to $2.5 \mathrm{~mm}$ in length, present in low abundances, up to 5\%. A few have skeletal morphologies in their outer rim, and some have sieved cores with a clear and zoned rim. Olivine phenocrysts (up to 5\%) are fresh and seriated up to $2 \mathrm{~mm}$ in size and frequently showing skeletal morphologies. Clinopyroxene is euhedral, up to $3 \%$ and $1 \mathrm{~mm}$ in size, and in some cases it can have markedly rounded corners.

Table 1 illustrates the principal petrographic characteristics of the volcanic units described above.

\subsection{Whole rock major elements geochemistry}

Payún Matrú Volcanic Field rocks belong to the alkaline series, ranging from basalts to trachytes (Hernando et al., 2011). The lavas of the basaltic fields have basaltic to trachybasaltic compositions (46.5-49.1\% $\mathrm{SiO}_{2}$ on an anhydrous basis) and the rocks of Payún Matrú and Payún Liso volcanoes have basaltic trachyandesitic to trachytic compositions (51.8-68.2\% $\mathrm{SiO}_{2}$ ). They define a linear trend in the TAS classification diagram, with a small gap of $2.7 \% \mathrm{SiO}_{2}$ separating both groups of rocks (Fig. 11). The younger basalts of Postcaldera Basalts II unit are all trachybasalts, while Post-caldera Basalts I and Pre-caldera Basalts units are both basalts and trachybasalts. The older unit of Payún Matrú, Pre-caldera Trachytes, has a wide range in composition compared to the younger trachytes of Post-caldera Trachytes unit, although it is mainly composed of trachytes. The most silicic pre-caldera lavas are porphyritic with clean sanidine phenocrysts, while in the other pre-caldera lavas plagioclase predominates over sanidine, and sieved phenocrysts are common. In both cases, the clinopyroxene and olivine is also present. The Portezuelo Ignimbrite is also trachytic (64.6-65.2\% $\mathrm{SiO}_{2}$ ), but with the eruption of the first post-caldera lavas, represented by the Post-caldera Trachyandesites unit, there is a marked shift to intermediate compositions (52.7-60\% $\mathrm{SiO}_{2}$ ). The post-caldera trachyandesitic intra-caldera lava flow possesses two different compositions (samples PM 13 with $60.08 \mathrm{SiO}_{2} \%$, and PM 34 with 54.43 $\mathrm{SiO}_{2} \%$, see Table 1 ). The vast majority of the flow is a basaltic trachyandesite and, in addition, it contains minor pockets of trachytic compositions which are discerned in the field just by a slight change in color. The most evolved rocks are those of Blocky Trachytes and Vitreous Trachytes lithofacies belonging to the Post-caldera Trachytes unit, along with very few representatives of pre-caldera trachytes. The tendency of the alkaline series is towards the rhyolite or phonolite fields, and in the particular case of the Payún Matrú Volcanic Field, the trachytes contain up to $14 \%$ of normative quartz and the most silicic ones plot close to the rhyolite field in the TAS diagram, suggesting that the evolution is towards more silicic compositions rather than to more alkaline products. Basaltic and trachybasaltic lavas from the basaltic fields are 


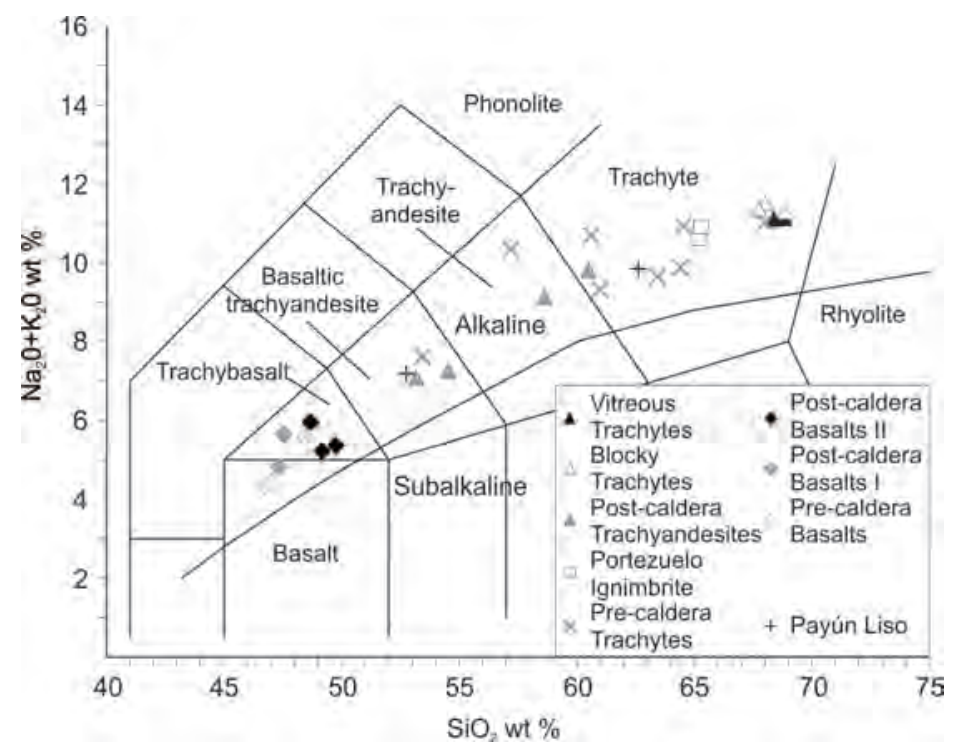

FIG. 11. TAS classification diagram for volcanic rocks (Le Maitre et al., 1989). Line separating the alkaline and subalkaline series according to Irvine and Baragar (1971).

TABLE 1. A BRIEF SUMMARY OF THE PETROGRAPHY OF THE PAYÚN MATRÚ VOLCANIC FIELD (WITH THE EXCEPTION OF PAYÚN LISO VOLCANO).

\begin{tabular}{|c|c|c|c|c|c|c|}
\hline \multirow{2}{*}{ mineral } & \multirow{2}{*}{$\begin{array}{l}\text { Pre-caldera } \\
\text { Trachytes }\end{array}$} & \multirow{2}{*}{$\begin{array}{l}\text { Portezuelo } \\
\text { Ignimbrite }\end{array}$} & \multirow{2}{*}{$\begin{array}{l}\text { Post-caldera } \\
\text { Trachyandesites }\end{array}$} & \multicolumn{2}{|c|}{ Post-caldera Trachytes } & \multirow{2}{*}{$\begin{array}{l}\text { Pre- and Post-caldera } \\
\text { Basalts I and II }\end{array}$} \\
\hline & & & & $\begin{array}{l}\text { Blocky } \\
\text { Trachytes }\end{array}$ & $\begin{array}{c}\text { Vitreous Trachytes }+ \\
\text { Pumiceous cones }\end{array}$ & \\
\hline Sanidine & $\begin{array}{c}8-20 \% \\
\text { with or without } \\
\text { plagioclase }\end{array}$ & \multirow{2}{*}{$\begin{array}{l}<25 \% \\
\text { Sanidine with } \\
\text { plagioclase. } \\
\text { Clean, a few } \\
\text { sieved. }\end{array}$} & --- & $\begin{array}{l}8-15 \% \\
\text { clean }\end{array}$ & $\begin{array}{l}8-15 \% \\
\text { clean }\end{array}$ & --- \\
\hline Plagioclase & $\begin{array}{c}8-20 \% \\
\text { with or without } \\
\text { sanidine. } \\
\text { Dusty and/or } \\
\text { coarse sieved } \\
\text { common. }\end{array}$ & & $\begin{array}{l}15-22 \% \\
\text { Clean plus dusty } \\
\text { common. } \\
\text { Rarely coarse } \\
\text { sieved. }\end{array}$ & --- & --- & $\begin{array}{l}\quad<5 \% \\
\text { Mostly clean, } \\
\text { a few sieved. }\end{array}$ \\
\hline Olivine & $1-3 \%$ & $1-2 \%$ & $<5 \%$ & $\begin{array}{l}<1 \% \\
\text { Not always } \\
\text { present }\end{array}$ & $1-2 \%$ & $\begin{array}{l}\quad<5 \% \\
\text { Euhedral and/or } \\
\text { skeletal. }\end{array}$ \\
\hline $\begin{array}{l}\text { Clino- } \\
\text { piroxene }\end{array}$ & $\begin{array}{l}\quad<3 \% \\
\text { Rounded and } \\
\text { unrounded. }\end{array}$ & $1-2 \%$ & $\begin{array}{l}\quad<5 \% \\
\text { Rounded and } \\
\text { unrounded. }\end{array}$ & $2-3 \%$ & $2-4 \%$ & $\begin{array}{l}<3 \% \\
\text { Sometimes } \\
\text { rounded. }\end{array}$ \\
\hline Amphibole & $\begin{array}{l}<2 \% \\
\text { Not always } \\
\text { present. } \\
\text { Opaque rim. }\end{array}$ & --- & --- & --- & --- & --- \\
\hline Biotite & $\begin{array}{c}<2 \% \\
\text { Not always } \\
\text { present. } \\
\text { Replaced by } \\
\text { anhidrous } \\
\text { minerals. }\end{array}$ & $\begin{array}{c}1 \% \\
\text { Without } \\
\text { replacements. }\end{array}$ & --- & $\begin{array}{c}1 \% \\
\text { Not always } \\
\text { present. } \\
\text { Replaced by } \\
\text { opaque } \\
\text { minerals. }\end{array}$ & $\begin{array}{l}<1 \% \\
\text { Not always } \\
\text { present. }\end{array}$ & $-\cdots$ \\
\hline $\begin{array}{c}\text { Fluid-fluid } \\
\text { relationship } \\
\text { groundmass }\end{array}$ & A few lavas. & --- & $\begin{array}{l}\text { Intra-caldera } \\
\text { flow. }\end{array}$ & $\cdots$ & --- & ---- \\
\hline
\end{tabular}


TABLE 2. MAJOR ELEMENTS, ${ }^{87} \mathrm{Sr} /{ }^{86} \mathrm{Sr}$ ISOTOPIC DATAAND NORMATIVE MINERALS (IN ITALICS) OF THE DIFFERENT UNITS OF THE PAYÚN MATRÚ VOLCANIC FIELD.

\begin{tabular}{|c|c|c|c|c|c|c|c|c|c|c|c|c|c|c|c|}
\hline \multirow{2}{*}{$\begin{array}{l}\text { Unit } \\
\text { Lithofacies } \\
\text { Sample }\end{array}$} & \multicolumn{6}{|c|}{ Post-caldera Trachytes } & \multicolumn{4}{|c|}{ Post-caldera trachyandesites } & \multicolumn{2}{|c|}{$\begin{array}{l}\text { Portezuelo } \\
\text { Ignimbrite }\end{array}$} & \multicolumn{3}{|c|}{ Pre-caldera Trachytes } \\
\hline & STA 24 & $\begin{array}{l}\text { eous Trach } \\
\text { PMA } 6 \text { P }\end{array}$ & $\begin{array}{l}\text { chytes } \\
\text { PMA 27-A }\end{array}$ & PM 40 & PM 47 & STA 37 & PM 13 & PM 34 & STA 6-B & STA 38 & $\begin{array}{c}\text { PM 14 } \\
\text { (Bulk rock) }\end{array}$ & $\begin{array}{c}\text { PMB 4 } \\
\text { (fiamme) }\end{array}$ & PM 25 & PM 27 & PM 28 \\
\hline \multicolumn{16}{|l|}{ wt $\%$} \\
\hline $\mathrm{SiO}_{2}$ & 67.83 & 67.61 & 68.18 & 67.24 & 68.25 & 66.48 & 60.08 & 54.43 & 58.39 & 52.75 & 64.60 & 65.16 & 67.71 & 63.66 & 63.03 \\
\hline $\mathrm{TiO}_{2}$ & 0.385 & 0.423 & 0.428 & 0.447 & 0.426 & 0.457 & 1.270 & 1.705 & 1.312 & 1.874 & 0.609 & 0.620 & 0.303 & 0.713 & 0.771 \\
\hline $\mathrm{Al}_{2} \mathrm{O}_{3}$ & 15.26 & 15.58 & 15.65 & 15.63 & 14.87 & 15.49 & 17.41 & 17.53 & 18.04 & 17.63 & 16.92 & 17.34 & 15.75 & 16.93 & 17.17 \\
\hline $\mathrm{Fe}_{2} \mathrm{O}_{3}(\mathrm{~T})$ & 2.94 & 3.02 & 3.10 & 2.95 & 3.05 & 3.04 & 5.69 & 8.44 & 6.12 & 8.90 & 3.40 & 3.38 & 3.34 & 3.95 & 4.5 \\
\hline $\mathrm{MnO}$ & 0.124 & 0.125 & 0.128 & 0.108 & 0.130 & 0.116 & 0.131 & 0.141 & 0.140 & 0.154 & 0.097 & 0.089 & 0.125 & 0.104 & 0.123 \\
\hline $\mathrm{MgO}$ & 0.28 & 0.31 & 0.32 & 0.32 & 0.35 & 0.38 & 1.40 & 3.41 & 1.81 & 3.38 & 0.57 & 0.61 & 0.28 & 0.93 & 1.07 \\
\hline $\mathrm{CaO}$ & 0.64 & 0.70 & 0.70 & 0.71 & 0.76 & 0.89 & 3.19 & 6.47 & 4.15 & 6.86 & 1.79 & 1.95 & 0.95 & 2.56 & 2.81 \\
\hline $\mathrm{Na}_{2} \mathrm{O}$ & 5.55 & 5.61 & 5.64 & 6.13 & 5.83 & 5.56 & 5.81 & 4.66 & 5.34 & 4.52 & 5.83 & 5.66 & 6.04 & 5.55 & 5.55 \\
\hline $\mathrm{K}_{2} \mathrm{O}$ & 5.41 & 5.40 & 5.44 & 5.25 & 5.36 & 5.58 & 3.94 & 2.58 & 3.76 & 2.51 & 4.98 & 4.96 & 4.94 & 4.21 & 4.04 \\
\hline $\mathrm{P}_{2} \mathrm{O}_{5}$ & 0.06 & 0.09 & 0.09 & 0.08 & 0.07 & 0.10 & 0.41 & 0.49 & 0.56 & 0.66 & 0.15 & 0.17 & 0.12 & 0.24 & 0.29 \\
\hline LOI & 0.43 & 0.43 & 0.38 & 0.32 & 0.52 & 0.55 & 0.31 & $<0.01$ & 0.42 & 0.38 & 0.31 & 0.13 & 0.32 & 0.16 & 0.36 \\
\hline Total & 98.92 & 99.29 & 100.10 & 99.18 & 99.61 & 98.66 & 99.63 & 99.83 & 100.00 & 99.62 & 99.27 & 100.10 & 99.89 & 99.01 & 99.73 \\
\hline Qz & 13.76 & 12.96 & 13.09 & 10.46 & 12.89 & 11.28 & 4.09 & 1.03 & 3.25 & 0.00 & 7.91 & 8.78 & 11.99 & 9.52 & 8.77 \\
\hline Hy & 0.03 & 0.25 & 0.27 & 0.00 & 0.24 & 0.00 & 2.17 & 6.55 & 3.69 & 6.72 & 0.40 & 0.97 & 0.00 & 1.59 & 2.09 \\
\hline Ol & 0.00 & 0.00 & 0.00 & 0.00 & 0.00 & 0.00 & 0.00 & 0.00 & 0.00 & 0.07 & 0.00 & 0.00 & 0.00 & 0.00 & 0.00 \\
\hline $\mathrm{Ne}$ & 0.00 & 0.00 & 0.00 & 0.00 & 0.00 & 0.00 & 0.00 & 0.00 & 0.00 & 0.00 & 0.00 & 0.00 & 0.00 & 0.00 & 0.00 \\
\hline${ }^{87} \mathrm{Sr} /{ }^{86} \mathrm{Sr}$ & \multicolumn{3}{|c|}{0.704288} & \multicolumn{3}{|l|}{0.704076} & \multicolumn{3}{|c|}{0.704021} & 0.703984 & & & \multicolumn{3}{|c|}{0.703970} \\
\hline Error & \multicolumn{3}{|c|}{ \pm 0.000027} & \multicolumn{3}{|l|}{ \pm 0.000035} & \multicolumn{3}{|c|}{ \pm 0.000045} & \pm 0.000037 & & & \multicolumn{3}{|c|}{ \pm 0.000043} \\
\hline $\mathrm{S}$ & $36^{\circ} 23.316^{\prime}$ & $36^{\circ} 22.603^{\prime}$ & $36^{\circ} 25.688^{\prime}$ & $36^{\circ} 23.641^{\prime}$ & $36^{\circ} 26.455^{\prime}$ & $36^{\circ} 27.920^{\circ}$ & $36^{\circ} 22.820^{\prime}$ & $36^{\circ} 23.418^{\prime}$ & $36^{\circ} 20.001^{\prime}$ & $36^{\circ} 28.001^{\prime}$ & $36^{\circ} 22.500^{\prime}$ & $36^{\circ} 22.516^{\prime}$ & $36^{\circ} 22.930^{\prime}$ & $36^{\circ} 22.848^{\prime}$ & $36^{\circ} 22.031^{\prime}$ \\
\hline W & $69^{\circ} 17.831^{\prime}$ & $69^{\circ} 14.269^{\prime}$ & $69^{\circ} 09.609^{\prime}$ & $69^{\circ} 13.221^{\prime}$ & $69^{\circ} 22.958^{\prime}$ & $69^{\circ} 18.491^{\prime}$ & $69^{\circ} 11.896^{\prime}$ & $69^{\circ} 13.025^{\prime}$ & $69^{\circ} 18.710^{\prime}$ & $69^{\circ} 17.745^{\prime}$ & $69^{\circ} 11.832^{\prime}$ & $69^{\circ} 11.824^{\prime}$ & $69^{\circ} 09.006^{\prime}$ & $69^{\circ} 10.991^{\prime}$ & $69^{\circ} 10.815^{\prime}$ \\
\hline Unit & \multicolumn{5}{|c|}{ Pre-caldera Trachytes } & \multicolumn{3}{|c|}{$\begin{array}{c}\text { Post-caldera } \\
\text { Basalts II }\end{array}$} & $\begin{array}{r}\text { Post-c } \\
\text { Bas }\end{array}$ & $\begin{array}{l}\text { caldera } \\
\text { alts I }\end{array}$ & & $\begin{array}{l}\text { re-caldera } \\
\text { Basalts }\end{array}$ & & Payú & in Liso \\
\hline Sample & PY 10 & PMA 64 & PMA 67 & PMA 74 & PMD 53 & PM-45 & PM-46 & PY 13 & STA 16 & STA 26 & PY 5 & PY 15 & STA 8 & STA 50 & STA 52 \\
\hline wt $\%$ & & & & & & & & & & & & & & & \\
\hline $\mathrm{SiO}_{2}$ & 59.96 & 60.30 & 63.99 & 52.44 & 56.03 & 49.04 & 49.13 & 48.15 & 47.21 & 47.16 & 48.69 & 46.52 & 47.22 & 51.88 & 62.10 \\
\hline $\mathrm{TiO}_{2}$ & 0.891 & 0.943 & 0.575 & 1.921 & 1.592 & 1.864 & 1.975 & 2.073 & 2.307 & 2.271 & 2.40 & 2.358 & 1.774 & 2.054 & 0.972 \\
\hline $\mathrm{Al}_{2} \mathrm{O}_{3}$ & 17.73 & 17.94 & 17.19 & 17.56 & 17.27 & 16.92 & 16.61 & 17.57 & 16.23 & 17.80 & 17.59 & 17.40 & 17.31 & 16.93 & 17.18 \\
\hline $\mathrm{Fe}_{2} \mathrm{O}_{3}(\mathrm{~T})$ & 5.24 & 5.27 & 4.11 & 9.01 & 7.56 & 10.71 & 10.17 & 10.74 & 12.46 & 11.26 & 11.18 & 12.17 & 11.35 & 9.14 & 5.33 \\
\hline $\mathrm{MnO}$ & 0.142 & 0.143 & 0.129 & 0.153 & 0.163 & 0.155 & 0.153 & 0.162 & 0.182 & 0.168 & 0.166 & 0.168 & 0.17 & 0.166 & 0.155 \\
\hline $\mathrm{MgO}$ & 1.36 & 1.13 & 0.53 & 2.54 & 1.59 & 6.44 & 5.72 & 4.64 & 6.27 & 5.13 & 5.03 & 5.89 & 6.59 & 2.96 & 0.99 \\
\hline $\mathrm{CaO}$ & 3.36 & 2.72 & 1.61 & 6.25 & 3.58 & 9.11 & 9.30 & 9.07 & 9.78 & 9.18 & 9.35 & 10.30 & 11.06 & 7.23 & 2.36 \\
\hline $\mathrm{Na}_{2} \mathrm{O}$ & 5.44 & 5.95 & 5.81 & 4.29 & 5.91 & 3.72 & 3.74 & 4.13 & 3.57 & 4.14 & 3.90 & 3.37 & 3.37 & 4.43 & 5.77 \\
\hline $\mathrm{K}_{2} \mathrm{O}$ & 3.73 & 4.69 & 5.04 & 3.19 & 4.26 & 1.49 & 1.56 & 1.76 & 1.24 & 1.47 & 1.72 & 0.94 & 1.06 & 2.65 & 3.99 \\
\hline $\mathrm{P}_{2} \mathrm{O}_{5}$ & 0.48 & 0.42 & 0.19 & 0.80 & 0.75 & 0.49 & 0.43 & 0.68 & 0.53 & 0.73 & 0.59 & 0.51 & 0.43 & 0.95 & 0.37 \\
\hline LOI & 0.55 & 0.05 & 0.27 & 1.93 & 0.95 & $<0.01$ & 0.02 & -0.48 & -0.57 & -0.30 & 0.33 & 0.19 & -0.08 & 1.46 & 0.20 \\
\hline Total & 98.89 & 99.55 & 99.44 & 100.10 & 99.65 & 99.78 & 98.81 & 98.50 & 99.22 & 99.00 & 100.90 & 99.80 & 100.30 & 99.85 & 99.4 \\
\hline Qz & 5.96 & 1.78 & 7.23 & 0.80 & 0.00 & 0.00 & 0.00 & 0.00 & 0.00 & 0.00 & 0.00 & 0.00 & 0.00 & 0.08 & 7.66 \\
\hline Hy & 3.82 & 1.98 & 1.11 & 5.77 & 0.00 & 0.00 & 0.00 & 0.00 & 0.00 & 0.00 & 0.00 & 0.00 & 0.00 & 5.11 & 2.58 \\
\hline Ol & 0.00 & 0.00 & 0.00 & 0.00 & 1.68 & 10.12 & 7.88 & 6.67 & 9.70 & 8.10 & 6.89 & 9.61 & 9.52 & 0.00 & 0.00 \\
\hline $\mathrm{Ne}$ & 0.00 & 0.00 & 0.00 & 0.00 & 1.28 & 0.71 & 0.60 & 3.44 & 1.94 & 4.17 & 2.15 & 1.36 & 3.25 & 0.00 & 0.00 \\
\hline${ }^{87} \mathrm{Sr}{ }^{86} \mathrm{Sr}$ & 0.703802 & & & & & & 0.703865 & & & & 0.703766 & 0.703906 & & & \\
\hline Error & \pm 0.000041 & & & & & & \pm 0.000042 & & & & \pm 0.000031 & \pm 0.000035 & & & \\
\hline $\mathrm{S}$ & $36^{\circ} 24.625^{\prime}$ & $36^{\circ} 22.997^{\prime}$ & $36^{\circ} 23.371^{\prime}$ & $36^{\circ} 23.732^{\prime}$ & $36^{\circ} 23.388^{\prime}$ & $36^{\circ} 18.142^{\prime}$ & $36^{\circ} 20.270^{\prime}$ & $36^{\circ} 23.748^{\prime}$ & $36^{\circ} 23.130^{\prime}$ & $36^{\circ} 18.673^{\prime}$ & $36^{\circ} 18.153^{\prime}$ & $36^{\circ} 23.226^{\prime}$ & $36^{\circ} 20.076^{\prime}$ & $36^{\circ} 29.591^{\prime}$ & $36^{\circ} 29.516^{\prime}$ \\
\hline W & $69^{\circ} 06.600^{\prime}$ & $69^{\circ} 10.644^{\prime}$ & $69^{\circ} 10.384^{\prime}$ & $69^{\circ} 10.108^{\prime}$ & $69^{\circ} 10.126^{\prime}$ & $69^{\circ} 19.884^{\prime}$ & $69^{\circ} 23.733^{\prime}$ & $69^{\circ} 03.493^{\prime}$ & $69^{\circ} 21.010^{\prime}$ & $69^{\circ} 17.246^{\prime}$ & $69^{\circ} 04.691^{\prime}$ & $69^{\circ} 02.488^{\prime}$ & $69^{\circ} 19.471^{\prime}$ & $69^{\circ} 16.503^{\prime}$ & $69^{\circ} 16.880^{\prime}$ \\
\hline
\end{tabular}

olivine and nepheline normative (6.6-10.1\% and 0.6-4.2\%, respectively, see Table 1 ), as expected for alkaline basalts. Stern et al. (1990) reported the chemistry and ${ }^{87} \mathrm{Sr} /{ }^{86} \mathrm{Sr}$ isotopic ratio of a basalt from 'Los Volcanes', having similar values as the analysis reported in the present work.
Figure 12 shows variation diagrams for major elements, where the samples define linear trends. $\mathrm{K}_{2} \mathrm{O}$ and $\mathrm{Na}_{2} \mathrm{O}$ have positive correlations with $\mathrm{SiO}_{2}$ while $\mathrm{MgO}, \mathrm{Fe}_{2} \mathrm{O}_{3}(\mathrm{~T}), \mathrm{CaO}$ and $\mathrm{TiO}_{2}$ (not shown) have negative correlations. $\mathrm{Al}_{2} \mathrm{O}_{3}$ is relatively constant with the increment of $\mathrm{SiO}_{2}$ content in basic and 

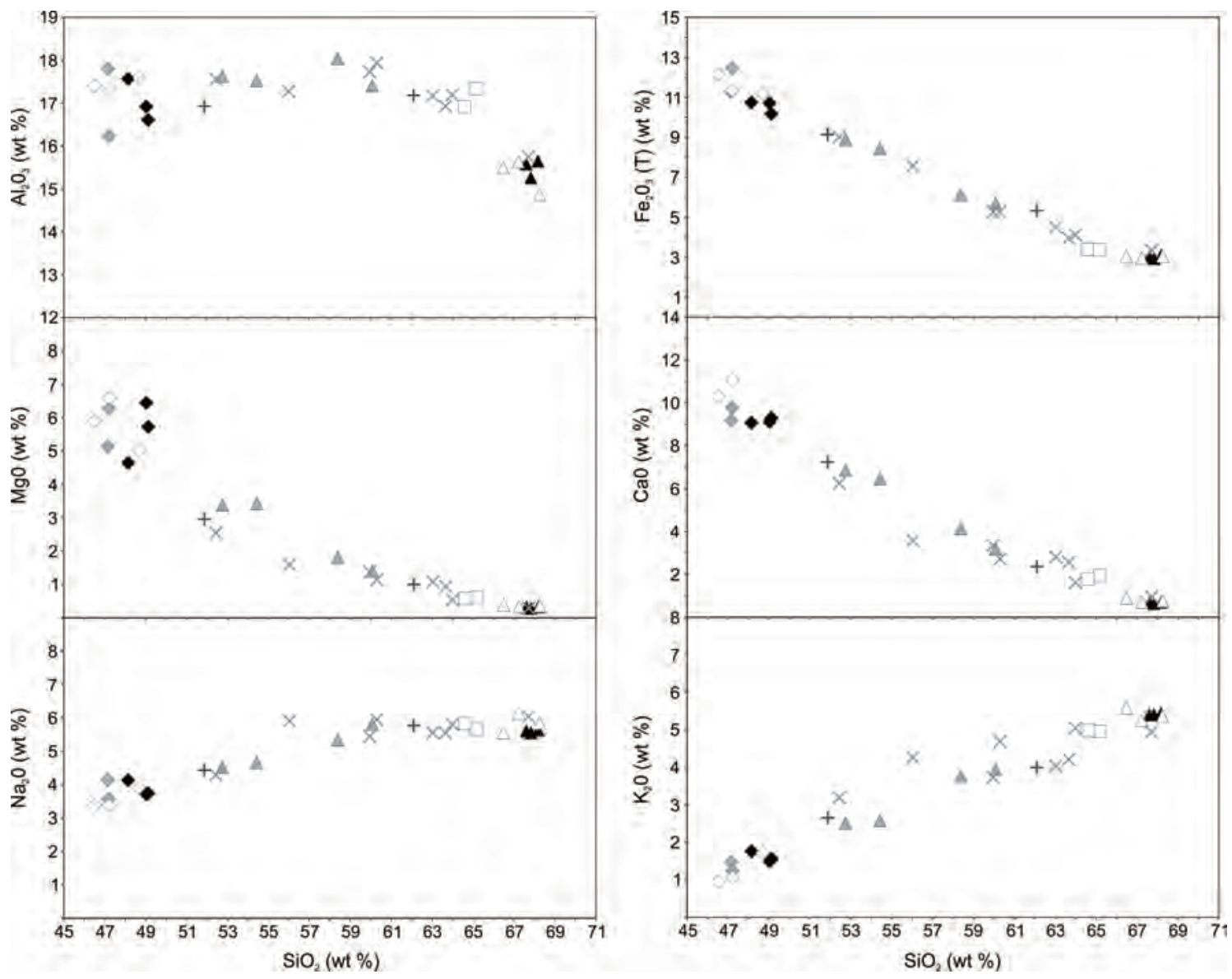

FIG. 12. Harker diagrams for major elements, showing a linear and continuous trend. See figure 11 for references.

intermediate compositions, decreasing in the more silicic rocks (around $66 \% \mathrm{SiO}_{2}$ ) belonging to the Blocky Trachytes and Vitreous Trachytes lithofacies, and in a few Pre-caldera Trachytic lavas.

\section{5. ${ }^{87} \mathrm{Sr} /{ }^{86} \mathrm{Sr}$ isotopic ratio}

The analysis of the ${ }^{87} \mathrm{Sr} /{ }^{86} \mathrm{Sr}$ isotopic ratio in the 9 samples indicates a narrow range in their values, between 0.703766 and 0.704288 (Table 1). These values correspond to both the basaltic lavas (Precaldera Basalts and Post-caldera Basalts II units) of the basaltic fields, and to the basaltic trachyandesitic to trachytic lavas (Pre-caldera Trachytes, Post-caldera Trachyandesites and Post-caldera Trachytes units) of the Payún Matrú volcano (see Table 1). The ${ }^{87} \mathrm{Sr} /{ }^{86} \mathrm{Sr}$ isotopic ratio indicates that the magmas were originated in the mantle, as previously proposed for the basaltic lavas of Payenia (Kay et al., 2004).

\section{Discussion}

\subsection{Volcanic stratigraphy}

The volcanic stratigraphy of the Payún Matrú Volcanic Field was modified from Llambías (1966) on the basis of new field, petrographic and geochemical information. The Portezuelo Ignimbrite lead to the separation in a pre-, syn-, and post-caldera stages (Fig. 6). In the pre-caldera stage, basaltic eruptions took place in the eastern and western basaltic field and basaltic trachyandesitic to trachytic magmas formed the pre-caldera Payún Matrú edifice, along with the neighboring Payún Liso stratovolcano. The syn-caldera stage is represented by the Portezuelo Ignimbrite and the formation of the $8 \mathrm{~km}$ wide caldera. The post-caldera stage continued in Payún Matrú, the basaltic fields (mostly in the western field), and not at all in Payún Liso. The Post-caldera Trachy- 
andesites were grouped originally along with some of the Post-caldera Basalts I lavas (Llambías, 1966). We postulate the definition of a new unit -Post-caldera Trachyandesites- due to their different composition and their belonging to the Payún Matrú volcano. The remaining post-caldera rocks (Post-caldera Trachytes unit, with its three lithofacies- Blocky Trachytes, Pumice cones and Vitreous Trachytes) are defined similarly as in Llambías (1966), but we grouped them in a different way due to their homogeneous trachytic compositions and their complex stratigraphic relationships (Fig. 6). The post-caldera basaltic lavas and scoria cones from the eastern and western basaltic fields were also grouped differently than the corresponding ones from Llambías (1966), according to the geological map presented and the contemporaneity of the basaltic fisural eruptions with the eruptions in the Payún Matrú volcano.

\subsection{Evidence of magma mixing and mingling}

In the Payún Matrú Volcanic Field there are several lines of evidence for magma mixing and/ or mingling, at different scales. For instance, the numerous E-W and NW-SE fisural basaltic eruptions are interrupted by the presence of a trachytic Payún Matrú composite volcano (Figs. 3a and 5). The absence of basaltic lavas in the caldera region suggests that the basaltic magmas were unable to reach the surface, most probably due to the presence of a magmatic chamber below the Payún Matrú caldera. This chamber would have acted as a barrier for the basaltic lavas rising from deeper levels if the chamber had been sufficiently melted, a likely condition as proved by the contemporaneity of both types of volcanism.

On the other hand, the petrographic study of the different units allowed us to discern several disequilibrium textures, the majority of which are attributed to magma mixing. According to experimental studies, the dusty zones in plagioclase phenocrysts are formed by partial dissolution of a plagioclase which is more sodic than the one that would be in equilibrium with the melt (Tsuchiyama, 1985). The conservation of the euhedral shape means that the crystal was below the liquidus curve for the plagioclase, and the rounding of crystals occurs if they were above the liquidus curve (Tsuchiyama, 1985).

A sieve texture in plagioclase, coarser than dusty zones but not as coarse as the coarse sieve texture, has been reproduced in hydrous experiments (Nakamura and Shimakita, 1998). This texture was interpreted as a partial dissolution of the plagioclase crystals, as in the anhydrous experiments carried out by Tsuchiyama (1985). The proposed scenario for this coarse sieved dissolution texture is magma mixing and frequently sieved and unsieved phenocrysts occur side by side, due to the mixing processes (Tsuchiyama, 1985; Stimac and Pearce, 1992; Tepley III et al., 1999; Nakamura and Shimakita, 1998).

Coarse sieve textures in plagioclase are interpreted as a result of rapid decompression with minor heat loss, rather than magma mixing (Nelson and Montana, 1992). The decompression of the system takes the plagioclase equilibrium composition to a more calcic composition, and this change is greater with the addition of the diopside component to the system, a likely condition in the Payún Matrú Volcanic Field as seen in the widespread occurrence of clinopyroxene in all its volcanic products (Nelson and Montana, 1992).

Mafic minerals may also show disequilibrium textures, but because of the faster diffusion of Fe$\mathrm{Mg}$ with respect to the diffusion of $\mathrm{CaAl}-\mathrm{NaSi}$, these textures are less likely to be preserved (Nakamura and Shimakita, 1998). Biotite breaks down into a reaction rim of anhydrous minerals by a number of reasons, such as changes in the $\mathrm{H}_{2} \mathrm{O}$ content of the melt or bulk composition or pressure. An accepted explanation to this is by rising the temperature of the host magma due to the intrusion of a mafic magma batch at the base of a magma chamber (Feeley and Sharp, 1996; Tepley III et al., 1999). Considering the mineral textures and association where the dehydrated biotite crystals occur, the most reasonable explanation for the reaction rims in biotite is magma mixing.

Opaque rims in amphiboles are common in volcanic rocks and are not necessarily related to magma mixing processes. In magmas ascending slowly from the storage zone at depth, the decompression and the loss of volatiles can produce the instability of amphibole and the reaction rim (Tepley III et al., 1999, Rutherford and Hill, 1993), which may be due to decompression or by mixing with another magma poor in volatiles (Kusçu and Floyd, 2001). Clinopyroxene destabilizes by nucleating Fe-Ti oxides and rendering it opaque, in decompression experiments (Nelson and Montana, 1992).

These mineralogical disequilibrium textures considered above, formed either by decompression 
or magma mixing, occur widely in the pre-caldera stage of Payún Matrú. The occurrence of dusty and coarse sieved zones in plagioclase phenocrysts is common (Fig. 9a), as the reaction rims with anhydrous minerals in biotite (Fig. 9b) and the opaque rim in amphibole (Fig. 9c), when these minerals are present. A few cases of magma mingling are present in the Pre-caldera Trachytes unit, showing the same mineralogical disequilibria textures named above (Fig. 9d).

The origin of the explosive eruption that deposited the Portezuelo Ignimbrite is somehow obscure. There have been cases in which the intrusion of mafic magma into a more silicic chamber triggered the explosive eruption, by producing the heating of the silicic magma and the exsolution of volatiles. This, in turn, would increase the pressure in the relatively shallow magmatic chamber and provide the energy required for the eruption (Kuritani, 2001; Kennet and Eichelberg, 1997; Snyder, 2000; Leonard et al., 2002; Shane et al., 2007). Also, the release of volatiles from the dehydration of amphibole and biotite can produce the vesiculation of the magma and the subsequent eruption (Tepley III et al., 1999). Considering the widespread occurrence of magma mixing and mingling in the pre-caldera stage, this explanation would seem the most reasonable one for the origin of the explosive eruption. Nevertheless, the petrography of the Portezuelo Ignimbrite does not show the same mineralogical disequilibrium textures of the Pre-caldera Trachytes unit, with the exception of some coarse sieved feldspars (Fig. 9e). Biotite crystals do not show signs of thermal instabilities (Fig. 9f). If the intrusion of mafic magma into the trachytic magma chamber of Payún Matrú was the triggering factor for the explosive phase of the Portezuelo Ignimbrite, it may be possible that these magmas formed a not mixed cap in the top of the magma chamber. This matter is still under consideration and needs further studies.

In the early post-caldera stage, represented by the Post-caldera Trachyandesites unit, the abundance of dusty zones in euhedral and also in rounded plagioclases is widespread, and they are present along with clean and euhedral plagioclases (Fig. 10a, b). The large variety of plagioclase textures and their abundance is a characteristic that is compatible with magma mixing processes. In the intra-caldera basaltic trachyandesitic lava flow, the mingling process, although not very discernible in the field, is evident in a microscopic scale and also in whole rock geochemical analysis (samples PM 13 and 34, Table 1), with pockets of trachytic magma immersed in basaltic trachyandesitic lava (Fig. 9d). Mixing processes were much more common than mingling ones, indicating that the proportion of the mafic end-member was high ( $>30 \%$ ) or, less likely, that the compositional differences were low $\left(<10 \% \mathrm{SiO}_{2}\right)$, otherwise, mafic enclaves would have formed in the more silicic magma (Stimac and Pearce, 1992; Tepley III et al., 1999; Kusçu and Floyd, 2001).

The late post-caldera stage, represented by the Post-caldera Trachytes unit with its three lithofacies, does not show reabsorption textures characteristic of magma mixing (Fig. 10e and 10f). Although the eruption style of the lithofacies changed from effusive to slightly explosive and again to effusive, the whole rock trachytic composition of the magmas remained relatively constant. Based on their morphology and textural characteristics of the deposits, the Pumice cones lithofacies is interpreted as very proximal pyroclastic fall deposits, analogous to their mafic equivalents, the scoria cones. The Vitreous Trachytes lithofacies is interpreted to be the degasified equivalent of the magma that formed the pumiceous cones, considering the field relations and petrographic characteristics.

The values of the initial ${ }^{87} \mathrm{Sr} /{ }^{86} \mathrm{Sr}$ isotopic ratio of both basalts and trachytes lie close to the present day mean mantle values of 0.704 , and show narrow ranges, suggesting little contamination with radiogenic crust. Only in the younger post-caldera trachytes of the Post-caldera Trachytes unit there is a slight increase in this value. The homogeneous ${ }^{87} \mathrm{Sr} /{ }^{86} \mathrm{Sr}$ isotopic ratio along with the linear trends in the TAS and Harker diagrams for major elements (Figs. 11 and 12) are consistent with the idea that the trachytic lavas are differentiated products of the basalts. The ${ }^{87} \mathrm{Sr} /{ }^{86} \mathrm{Sr}$ isotopic ratio of Payún Matrú Volcanic Field rocks indicates that either the magmas are fractioned from mantle derived magmas, or that they are mixtures of mantle derived magmas and melts of magmas with isotopic ratios like the mantle magmas. The silicic lavas could be partial melts of underplated mantle derived basalt.

Since in bivariate diagrams hybrid magmas must lie along a tie line connecting the end-members of the mixing products, the Post-caldera Trachyandesites and some hybrid Pre-caldera Trachytes unit lavas would represent a mixture between magmas of basaltic and trachytic compositions, being the evolved member 
of pre-caldera trachytes type and not of post-caldera trachytes type. This is easily discernible in the Harker diagram for $\mathrm{Al}_{2} \mathrm{O}_{3}$ (Fig. 12), where the younger trachytes have a significantly lower value of $\mathrm{Al}_{2} \mathrm{O}_{3}$ than it would be expected for the more silicic end-member of the mixed products. Post-caldera Trachyandesites unit lavas and the hybrid or mingled lavas of the Pre-caldera Trachytes unit do not coincide with the tie line connecting the Post-caldera Trachytes and basaltic extreme compositions.

\section{Conclusions}

The Payún Matrú Volcanic Field is one of the two basaltic fields of the Payenia Basaltic Province, the largest Quaternary basaltic province present in the Andes back-arc of South America. The Payún Matrú Volcanic Field comprises two composite volcanoes (Payún Matrú with a circular summit caldera and Payún Liso stratovolcano) along with basaltic fields east and west of the Payún Matrú caldera.

The Payún Matrú Volcanic Field is a notable example of magma mixing, where the end-members of this mixing process are side by side in the field, showing two contrasting styles of volcanic activity: one forming a volcanic field with numerous monogenic basaltic cones and lava flows, and the other forming a polygenic volcano with a single shield-shaped edifice built by successive effusive and explosive eruptions, the Payún Matrú. Basaltic magmas originated in the mantle were erupted forming basaltic fields, with their eruptions controlled by NW-SE and E-W fissures. The trachytic Payún Matrú volcano is a product of the differentiation of these basaltic magmas. With the exception of the latest stage when the more evolved trachytes erupted, the Payún Matrú history was marked by recurrent mixing processes of basaltic and trachytic magmas. Thus, magma mixing is the result of injection of basaltic magma coming from depth into a cogenetic trachytic magma chamber near the surface.

\section{Acknowledgements}

We are grateful to the staff of Recursos Naturales Renovables of Malargüe, Argentina, for their support in the successive field work. We would like to thank A. Schiuma, L. Oliva, M. Galina, G. Páez and F. González Soto (Universidad Nacional de La Plata, Argentina) for their contributions in the field work. Special thanks to J. Franzese and A. Benialgo (Centro de Investigaciones
Geológicas, La Plata, Argentina) for the enlightening revision of the manuscript and for helping with the satellite imagery, respectively, and also to A. Richter (Universidad Nacional de La Plata, Argentina) for the revision of the manuscript. We also thank V. García and R. Varela (Centro de Investigaciones Geológicas, La Plata, Argentina) for helping in the laboratory procedures and techniques. Thanks to L. Gómez Peral (Centro de Investigaciones Geológicas, La Plata, Argentina) for providing a processed satellite image. Finally, we would like to thank the reviewers for the comments and suggestions that improved the article. This study was funded by projects UNLP N547 and N620 and CONICET PIP 0119, Argentina.

\section{References}

Bermúdez, A.; Delpino, D. 1989. La provincia basáltica andino cuyana. Revista de la Asociación Geológica Argentina 44 (1-4): 35-55.

Bermúdez, A.; Delpino, D.; Frey, F.; Saal, A. 1993. Los basaltos de retroarco extraandinos. In Congreso Geológico Argentino, No. 12 and Congreso de Exploración de Hidrocarburos, No. 2. Geología y Recursos Naturales de Mendoza (Ramos, V.A.; editor), Relatorio I (13): 161-172. Mendoza.

Feeley, T.C.; Sharp, Z.D. 1996. Chemical and hydrogen isotopic evidence for in situ dehydrogenation of biotite in silicic magma chamber. Geology 24: 1021-1024.

Folguera, A.; Naranjo, J.A.; Orihashi, Y.; Sumino, H.; Nagao, K. 2009. Retroarc volcanism in the northern San Rafael Block (34-35³0’S), southern Central Andes: Occurrence, age, and tectonic setting. Journal of Volcanology and Geothermal Research 186: 169-185.

Galland, O.; Hallot, E.; Cobbold, P.R.; Buffet, G. 2007. Volcanism in a compressional Andean setting: A structural and geochronological study of Tromen volcano (Neuquén province, Argentina). Tectonics 26 TC4010: 1-24.

Germa, A.; Quidelleur, X.; Gillot, P.Y.; Tchilinguirian, P. 2010. Volcanic evolution of the back-arc Pleistocene Payun Matru volcanic field (Argentina). Journal of South American Earth Sciences 29: 717-730.

González Díaz, E. 1970. Rasgos morfológicos del área volcánica del cerro-volcán Payún Matrú. Opera Lilloana 20: 102 p.

González Díaz, E. 1972. Descripción geológica de la Hoja 30d Payún Matrú. Dirección Nacional de Geología y Minería, Boletín 130: 92 p.

Hernando, I.R.; Llambías, E.J.; García, V. 2011. Caracterización geoquímica del volcán Payún Matrú, retroarco 
andino al sur de la provincia de Mendoza. In Congreso Geológico Argentino, No. 18, Actas: 486-487. Neuquén. Inbar, M.; Risso, C. 2001a. A morphological and morphometric análisis of a high density cinder cone volcanic field - Payun Matru, south-central Andes, Argentina. Zeitschrift für Geomorfologie 45 (3): 321-343.

Inbar, M.; Risso, C. 2001b. Holocene yardangs in volcanic terrains in the southern Andes. Earth Surface Processes and Landforms 26: 657-666.

Irvine, T.N.; Baragar, W.R.A. 1971. A guide to the chemical ckassification of the common volcanic rocks. Canadian Journal of Earth Sciences 8: 523-548.

Kay, S.M. 2002. Magmatic sources, tectonic setting and causes of tertiary to recent Patagonian plateau magmatism ( $36^{\circ} \mathrm{S}$ to $52^{\circ} \mathrm{S}$ latitude). In Congreso Geológico Argentino, No. 15, Actas 3: 95-100. Calafate.

Kay, S.M.; Gorring, M.; Ramos, V.A. 2004. Magmatic sources, setting and causes of Eocene to recent $\mathrm{Pa}$ tagonian plateau magmatism ( $36^{\circ} \mathrm{S}$ to $52^{\circ} \mathrm{S}$ latitude). Revista de la Asociación Geológica Argentina 59 (4): 556-568.

Kay, S.M.; Burns, W.M.; Copeland, P.; Mancilla, O. 2006a. Upper Cretaceous to Holocene magmatism and evidence for transient Miocene shallowing of the Andean subduction zone under the northern Neuquén Basin. In Evolution of an Andean margin: A tectonic and magmatic view from the Andes to the Neuquén Basin (35-395 latitude) (Kay, S.M.; Ramos, V.A.; editors). Geological Society of America, Special Paper 407: 19-60. Colorado.

Kay, S.M.; Mancilla, O.; Copeland, P. 2006b. Evolution of the late Miocene Chachahuén volcanic complex at $37^{\circ} \mathrm{S}$ over a transient shallow subduction zone under the Neuquén Andes. In Evolution of an Andean Margin: A tectonic and magmatic view from the Andes to the Neuquén Basin (35-39º lat.) (Kay, S.M.; Ramos, V.A.; editors). Geological Society of America, Special Paper 407: 215-246. Colorado.

Kennet, J.W; Eichelberg, J.C. 1997. Syneruptive mixing, degassing and crystallization at Redoubt volcano, eruption of december, 1989 to may 1990. Journal of Volcanology and Geothermal Research 75: 19-37.

Kuritani, T. 2001. Replenishment of a mafic magma in a zoned mafic magma chamber beneath Rishiri Volcano, Japan. Bulletin of Volcanology 62: 533-548.

Kusçu, G.G.; Floyd, P.A. 2001. Mineral compositional and textural evidence for magma mingling in the Saraykent volcanics. Lithos 56: 207-230.

Le Maitre, R.W.; Bateman, P.; Dudek, A.; Keller, J.; Lameyre, J.; Le Bas, M.J.; Sabine, P.A.; Schmid, R.; Sorensen,
H.; Streckeisen, A.; Woolley, A.R.; Zanettin, B. 1989. A classification of igneous rocks and glossary of terms: Recommendations of the International Union of Geological Sciences Subcommission on the Systematics of Igneous Rocks. Blackwell Scientific: 193 p. Oxford.

Leonard, G.S.; Cole, J.W.; Nairn, I.A.; Self, S. 2002. Basalt triggering of the c. AD 1305 Kaharoa rhyolite eruption, Tarawera Volcanic Complex, New Zealand. Journal of Volcanology and Geothermal Research 115: 461-486.

Llambías, E.J. 1966. Geología y petrología del volcán Payún Matrú. Acta Geológica Lilloana 8: 265-315.

Llambías, E.J.; Bertotto, G.W.; Risso, C.; Hernando, I.R. 2010. El volcanismo cuaternario en el retroarco de Payenia: una revisión. Revista de la asociación Geológica Argentina 67 (2): 278-300.

Nakamura, M.; Shimakita, S. 1998. Dissolution origin and syn-entrapment compositional change of melt inclusion in plagioclase. Earth and Planetary Science Letters 161: 119-133.

Nelson, S.T.; Montana, A. 1992. Sieve-textured plagioclase in volcanic rocks produced by rapid decompression. American Mineralogist 77: 1242-1249.

Pasquerè, G.; Bistacchi, A.; Francalanci, L.; Bertotto, G.W.; Boari, E.; Massironi, M.; Rossotti, A. 2008. Very long pahoehoe inflated basaltic lava flows in the Payenia Volcanic Province (Mendoza and La Pampa, Argentina). Revista de la Asociación Geológica Argentina 63 (1): 131-149.

Polanski, J. 1954. Rasgos geomorfológicos del territorio de la provincia de Mendoza. Instituto de Investigaciones Económicas y Tecnológicas, Cuadernos de Estudio e Investigación 4: 10 p. Mendoza.

Ramos, V.A. 1978. Estructura. In Geología y Recursos Naturales del Neuquén. In Congreso Geológico Argentino, No. 7, Relatorio: 99-118. Neuquén.

Ramos, V.A.; Kay, S.M. 2006. Overview of the tectonic evolution of the southern Central Andes of Mendoza and Neuquén (35-395 latitude). In Evolution of an Andean margin: A tectonic and magmatic view from the Andes to the Neuquén Basin (35-395 latitude) (Kay, S.M.; Ramos, V.A.; editors) Geological Society of America, Special Paper 407: 1-17. Colorado.

Ramos, V.A.; Folguera, A. 2010. Payenia volcanic province in the Southern Andes: An appraisal of an exceptional Quaternary tectonic setting. Journal of Volcanology and Geothermal Research 201 (1-4): 53-64

Rutherford, M.J.; Hill, P.M. 1993. Magma ascent rates from amphibole breakdown: An experimental study applied to the 1980-1986 Mount St. Helens eruptions. Journal of Geophisical Research 98 (11): 667-685. 
Shane, P.; Martin, S.B.; Smith, V.C.; Beggs, K.F.; Darragh, M.B.; Cole, J.W.; Nairn, I.A. 2007. Multiple rhyolite magmas and basalt injection in the $17.7 \mathrm{ka}$ Rerewhakaaitu eruption episode from Tarawera Volcanic Complex, New Zealand. Journal of Volcanology and Geothermal Research 164: 1-26.

Snyder, D. 2000. Thermal effects of the intrusion of basaltic magma into a more silicic magma chamber and implications for eruption triggering. Earth and Planetary Science Letters 175: 257-273.

Stern, C.R.; Frey, F.A.; Futa, K.; Zartman, R.E.; Peng, Z.; Kyser, T.K. 1990. Trace-element and Sr, Nd, Pb, and $\mathrm{O}$ isotopic composition of Pliocene and Quaternary alkali basalts of the Patagonian Plateau lavas of southernmost South America. Contributions to Mineralogy and Petrology 104: 294-308.
Stimac, J.A.; Pearce, T.H. 1992. Textural evidence of mafic-felsic magma interaction in dacite lavas, Clear Lake, California. American Mineralogist 77: 795-809.

Tepley III, F.J.; Davidson, J.P.; Clynne, M.A. 1999. Magmatic interactions as recorded in plagioclase phenocrysts of Chaos Crag, Lassen Volcanic Center, California. Journal of Petrology 40 (5): 787-806.

Tsuchiyama, A. 1985. Dissolution kinetics of plagioclase in the melt of the system diopside-albite-anorthite, and origin of dusty plagioclase in andesites. Contributions to Mineralogy and Petrology 89: 1-16.

Varela, R.; Roverano, D.; Sato, A.M. 2000. Granito El Peñón, sierra de Umango: descripción, edad Rb/Sr e implicancias geotectónicas. Revista de la Asociación Geológica Argentina 55 (4): 407-413. 